\title{
Implications for Culture Contact History from a Glass Artefact on a Diingwulung Earth Mound in Weipa
}

\author{
Billy Ó Foghlú, Daryl Wesley, Sally Brockwell and Helen Cooke
}

Department of Archaeology and Natural History, School of Culture, History and Language, College of Asia and the Pacific, Australian National University, Acton ACT 2601, Australia

billy.o.foghlu@anu.edu.au, daryl.wesley@anu.edu.au, sally.brockwell@anu.edu.au,helen.cooke@anu.edu.au

\begin{abstract}
This paper reports on a glass artefact found on an earth mound at Diingwulung in Wathayn Country, near Weipa, far north Queensland. Despite intense research efforts and cultural heritage management surveys over many years, and the fact that they have been reported commonly within the ethnographic literature, such artefacts have been found rarely outside of Aboriginal mission contexts. As well as describing the artefact, its location and the frontier contact complex of the area, this paper includes the background of knapped glass artefacts in Australia, archaeological and ethnographic descriptions of Indigenous glass use in far north Queensland and the methodology of glass artefact analysis. Although it is only a single artefact, we argue that this glass piece has much to reveal not only regarding its chronology, use, and the function of the site where it was found, but also about culture contact, persistence of traditional technology, connections to Country and the continuity and extent of postcontact Indigenous occupation of the area.
\end{abstract}

\section{Introduction}

A recurring theme in lithic analysis is that some artefact types can be ranked higher than others in importance when being used to interpret specific archaeological sites (see Andrefsky 2005; Clarkson 2002, 2007; Geneste et al. 2010; Hiscock and Attenbrow 1998; Hiscock 2008). The discovery of a single utilised glass flake at Diingwulung 32 earth mound in Wathayn Country, is one of only a very small number of recorded Indigenous flaked glass pieces outside of historic Aboriginal missions in the Weipa region, situated on western Cape York, Queensland (Figure 1) (Morrison et al. 2015).

The Weipa area has been one of the most intensively archaeologically studied regions in Cape York following many years of research on shell mounds and thousands of kilometres of pedestrian surveys for the Rio Tinto Alcan bauxite mining operation (see Bailey 1975, 1977, 1994, 1999; Bailey et al. 1994; Larsen et al. in press; Morrison 2010, 2013, 2014, 2015; Morrison et al. 2010, 2015; Shiner and Morrison 2009; Shiner et al. 2013; Stevenson et al. 2015).

However, there are few reported examples of postcontact glass artefacts on Indigenous archaeological sites (Morrison 2010) despite numerous ethnographic references to use of glass in the Cape and Torres Strait Island region. This situation is in contrast to the rich postcontact archaeological evidence of Indigenous utilisation of other introduced materials during the occupation of the Weipa Mission between 1898 to 1932 (Morrison et al. 2015). Post-contact land use is also demonstrated by the distribution of culturally modified trees (David and Wilson 1999; Manas et al. 2008; Morrison 2010; Morrison and Shepard 2013; Morrison et al. 2010, 2015; Shiner and Morrison 2009). Although Morrison (2010:267) highlights the social and economic significance of a single glass artefact find from the Mission River north of Weipa, there needs to be further investigation into modified glass finds in the region given the richness of glass utilisation demonstrated at sites of Indigenous engagement with European settlements, missions, and economies elsewhere in Australia (see Allen 1969, 2008; Beck and Somerville
2005; Cooper and Bowdler 1998; Gibbs and Harrison 2008; Harrison 2000, 2002, 2006, 2009; Niemoeller 1999; Niemoeller and Guse 1999).

The discovery and interpretation of a single utilised glass fragment from earth mound Diingwulung 32 is significant owing to the amount of information that can be learned about Indigenous cultural responses during the contact period. This glass artefact can also prove useful in providing a datable context for post-contact activity at a site that demonstrates continuity of Indigenous land-use. Pre-contact earth mound construction and occupation has proven difficult to interpret and even less is known about their utilisation in the post-contact period (Brockwell 2006; Ó Foghlú in press; Guse 2006; Shiner and Morrison 2009). Therefore we provide a framework for the study of Australian Indigenous glass artefacts in our examination of the Diingwulung 32 utilised glass artefact to emphasise its importance in the context of the post-contact Weipa region Aboriginal history. To paraphrase Bradley (1993) and Holtorf (1998) in a north Australian context, the latter use or reuse of an archaeological site is as important as its original function or purpose, in interpreting the entire life history of a site, as well as the culture that utilised it. The history of how Wathayn Country and the greater Weipa area became part of the maritime and pastoral frontiers within Cape York's contact complex will be discussed along with absences in local archaeological and ethnographic records. This period was very turbulent for local Aboriginal communities. It will be shown how a single diagnostic artefact associated with an earth mound site context from this time can contribute positively to collective memory and cultural identity in Wathayn today.

Conflict, Change and 'Contact' throughout Cape York This study deals with archaeological sites that saw utilisation before, through and after Cape York Peninsula's contact period. Understanding the nature of this contact is key to understanding the importance archaeological sites and artefacts can have both for the archaeological record of the region, and for cultural identities in Aboriginal communities today (Ó Foghlú in press). The Aboriginal 


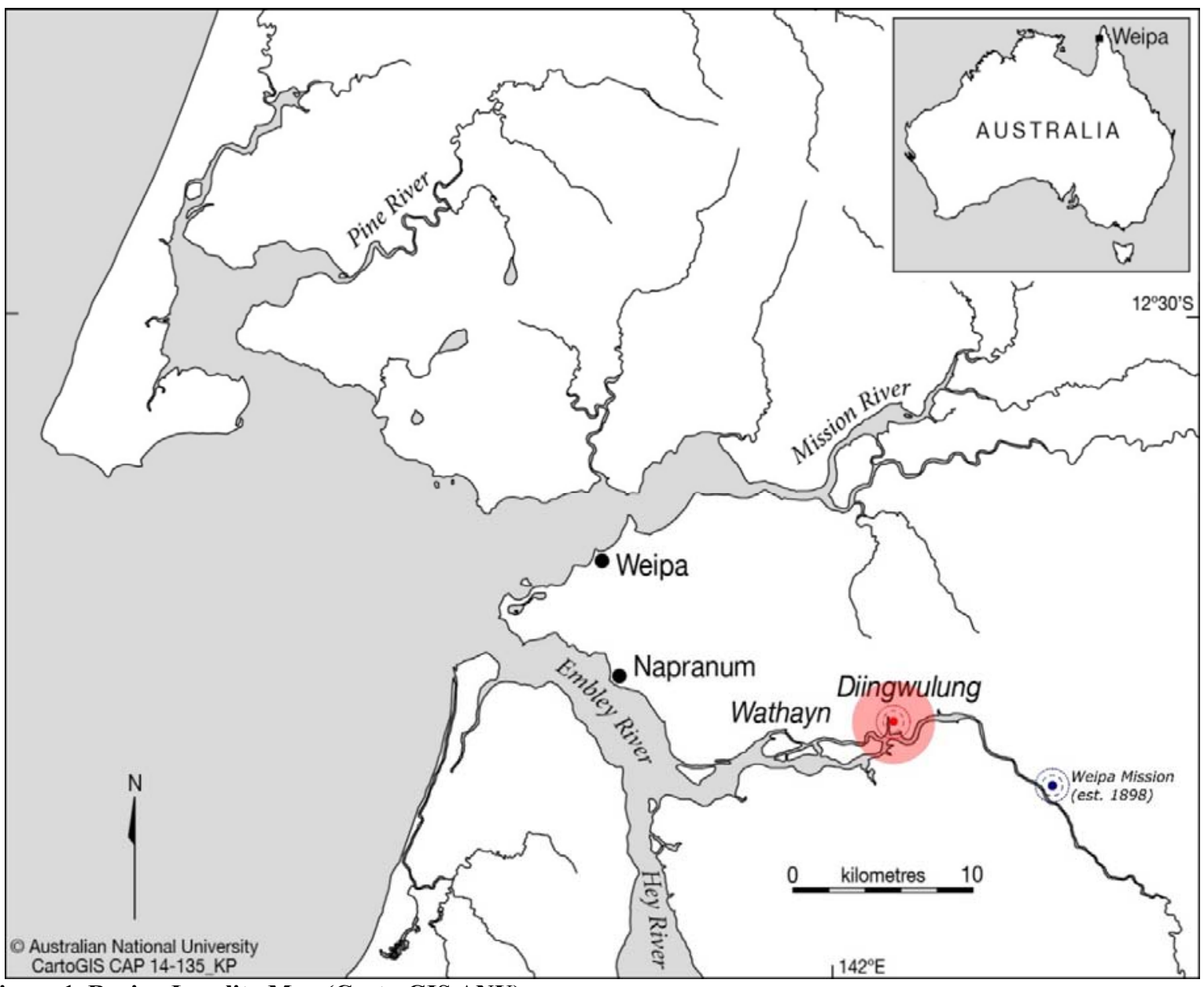

Figure 1. Region Locality Map (Carto-GIS ANU).

communities of Cape York Peninsula have experienced a long and tapestried history of external contact throughout the late Holocene period. Parts of Cape York, the Torres Strait and the Papuan mainland have, through degrees of connection, been part of the Torres Strait Cultural Complex for thousands of years (see Barham 2000).

This 'trans-Strait maritime cultural complex' may at times have extended 'south as far as Princess Charlotte Bay, and along the southwestern Papuan coast into the Fly River estuary, to the north and east' (Barham 2000:257). The ever expanding archaeological record of the Torres Strait for the mid-to-late Holocene reveals that changing land and seascapes were instigators to multiple reorganisations of settlement patterns and resource exploitation techniques. For this reason, it can be difficult to track the extent and duration of specific Cape York communities' level of contact with this cultural complex (Barham 2000; David et al. 2004; Davis 2004; Wright 2011; Wright and Jacobsen 2013). Oswald Brierly kept journals (Brierly 1849-1953a; Moore 1979) and sketchbooks (Brierly 1848, 1849, 1849-1953b) during his time aboard the HMS Rattlesnake on her voyages throughout this region between 1848 and 1850. Brierly's work demonstrates that at that time, the Torres Strait Cultural Complex was a cosmopolitan hub of interaction and exchange.

Europeans began charting the western coasts of Cape York over four centuries ago. The first recorded voyage

2 | 2019 | Vol. 19 | q a r was made by Dutch navigators uppermerchant Jan Lodewycksz Rosengeyn and skipper Willem Jansz along with their crew aboard the Duyfken in 1606 (Robert 1973:8). Subsequent voyages by other Dutch navigators of the Verenigde Oost-Indische Compagnie (United East India Company) followed over the next 150 years, albeit intermittently. Some of these voyages resulted in direct contact with Indigenous communities on Cape York (Robert 1973; Schilder 1975; Sheehan 2008; Sutton 2008).

There is also the possibility of contact or indirect influence (via trade) from 'Macassan' fishers along the Gulf of Carpentaria and up the south-western coast of Cape York in past centuries. Ludwig Leichhardt, who journeyed overland down the southwestern coast of Cape York in 1845 and around the cape aboard the Heroine in 1846, wrote of potential 'Macassan' influence in these places (Leichhardt 1845-1846:425-464, 1847:328, 414). These sentiments have been echoed by later explorers in the region (Blair and Hall 2013; Clark and May 2013; Loos 1982: 15-16; Reid 2013). For all of these reasons, as Loos (1982: xvii) writes, 'North Queensland has long been a frontier province of Aboriginal Australia'.

The European colonisation of north Queensland, which began in 1861 (Loos 1982:xvii), brought irremediable cataclysm to the region and its people. By the beginning of the twentieth century, this colonial conquest had claimed over 90\% of Queensland's Indigenous population (Bottoms 2013; Loos 1982). This conflict was not a 
systematic advance from one compass point to another, nor was it fought over clear border lines. As Loos (1982) explains, this invasion can be studied within the framework of four interwoven frontiers of contact: the pastoral, mining, sea and rainforest frontiers. Behind these frontiers both church and government sought to control the lives and actions of Aboriginal and Torres Strait Islander communities (Frankland 1994; Hey 1931).

The product of this control was a multi-racial society with clear economic and social stratification; a caste system which became enshrined in the Aboriginals Protection and Restriction of the Sale of Opium Act 1897 (Qld). This Act, its amendments and subsequent acts perpetuated enormous control over the lives of Indigenous peoples well into the twentieth century in what amounted to 'a Queensland version of Apartheid' (Taylor 2003:121). This control extended over matters of employment, sickness, marriage, travel, crime, deportation and death in ways that did not affect the colonial population (Blake 1998; Bottoms 2013; Frankland 1994; Gillett 1986; Loos 1982; Meston 1895, 1896; Taylor 2003). In addition to the catastrophic loss of life, by 1939 almost 7000 Aboriginal people in Queensland had been deported to reserves and missions under the Act (Blake 1998:51).

\section{The Shaping of Mapoon and Weipa's Frontier Complex}

It is difficult to look at any part of Weipa during this period without also looking at Mapoon, approximately $100 \mathrm{~km}$ to the north at Port Musgrave. The establishment of missions along the upper western coast of Cape York began at Mapoon in 1891. Missions were later established at Weipa in 1898 and even further south at Aurukun in 1904. Prior to colonial presence the Mapoon and Weipa regions shared a number of important networks. The Mapoon missionaries interacted extensively with communities all along these networks, and recorded a lot of these interactions (Ó Foghlú in press; Hey 1931; Hutton 1922; Ward 1908). Their accounts (Hey 1931; Ward 1908), and those of government officials who met with them (e.g. Embley 1897e; Meston 1896; Parry-Okeden 1897; Urquhart 1897), provide important insights into what this region was like prior to the enactment of the Aboriginals Protection and Restriction of the Sale of Opium Act 1897 (Qld).

The regions of Wathayn and the greater Weipa area became part of the greater contact complex through the establishment of maritime and pastoral frontiers during the mid-to-late nineteenth century. These permeable extensions of colonial society and autocratic control became intermeshed with the equally permeable and multifaceted boundaries that ran between and within the Aboriginal society and presence that had long established itself as an integral component of the landscape (Loos 1982; Ó Foghlú in press; Stevenson et al. 2015; Sutton 2008). The nature of this complex resulted in a population that collectively experienced multiple stages of contact simultaneously. Even during the period commentators noted that contact was a multistage process and not just a dichotomous social transition (Loos 1982:142). When the missionaries arrived at Mapoon in late 1891, after an earlier scoping expedition, they met with Indigenous communities whose collective experiences reflect the complexity of this process (Ward 1908:54-67). To begin with, eight people who had been kidnapped from the area by pearl shell fishers were being returned by the missionaries after being rescued on Thursday Island. These men, women and children were arriving back to Country in European clothing with direct experience of colonial society. A number of men at Mapoon surprised the missionaries because they shook hands in European fashion, wore shirts of European style and were known by English names. Other people present were wearing traditional styled clothing they had made from pieces of European material. Another group was far more apprehensive about the arrival because they had never seen a ship before and needed to be constantly reassured by the people who had. In addition, the missionaries could also see the smoke of a large fire in the distance; the makers of this fire were, to paraphrase the terms used, completely uncontacted (Ward 1908:54-67). Therefore at this single location in 1891 there were people whose experiences collectively spanned the full breadth of the contact spectrum.

Similarly, though there is less available evidence for Wathayn and the greater Weipa region for this time, the same complex can be discerned. In March 1891 George Smith, aboard the Vigilant on a search for commandeered vessels, went ashore with company in this area. The party encountered people who were completely uncontacted. These people wore no European clothes, repeated back any words said to them, and had absolutely no understanding of tobacco; universally one of the first and most traded commodities between colonial and Aboriginal communities at this time (Smith 1891). Survivors of the Kanahooka wreck came ashore in the same area in 1894, around three years after the establishment of the Mapoon mission to the north. These men were met by people whose contact experiences varied greatly, ranging from direct influence from the mission, to people who were completely uncontacted by the colonial population (Anon. 1894a, Anon. 1894b; Ward 1908:149-165).

Archibald Meston, an architect of the 1897 Act, explored the main rivers of Albatross Bay and the surrounding areas in 1896 (including an Indigenous camp on the southern edge of Wathayn). He encountered similar experiences; some of the local population had experienced a great deal of colonial contact, for instance tobacco was now a traded commodity. However other people in the same area had only indirect experiences or no experience of colonial contact (Blake 1998; Frankland 1994; Meston 1896, 1897a, 1897c-i; Taylor 2003). Meston's accounts are also an insight into the extensive networks that existed between Aboriginal groups in the Weipa area at this time both over land and water. These accounts demonstrate at least a partial understanding of why different people in the same location could have such vastly different experiences.

\section{The Sea Frontier}

The sea frontier had developed along the western coast of Cape York long before the missionaries emerged from it (Loos 1982:118-159), indeed one of the prime motives for establishing the missions was to combat the devastation brought by the conflict on this frontier (Hey 1931; Ward 1908). In the 1840s a small trade in bêche-de-mer and tortoiseshell had been established in the Torres Strait by voyagers from Sydney and Hong Kong. By the 1880s this trade had boomed into a sizable industry. A trade in pearl shell developed in the same region in the 1870s and had also boomed by the 1880 s. Both industries required a large, 
cheap labour force from the 1870s onwards. A large proportion of this force was kidnapped from many parts of the Torres Strait Cultural Complex and essentially enslaved. In other cases Indigenous people were deceived into entering terms of indentured servitude. Even in cases of willing employment, Indigenous people were often never paid, unfairly paid, cheated out of their wages or taken for terms far longer than those they had agreed to. Many became prisoners at sea or were marooned until the fisher required their labour again. In other cases people were traded like property, left to die in unknown country, or shot and thrown overboard. On the coasts of Cape York, many attempts at kidnapping ended in massacres (Bottoms 2013; Hey 1931; Loos 1982:118-159; Meston 1896, 1897a, 1897c-i; Roth 1900b-c, 1901e, 1902f, 1903e, 1904b, 1905b, 1906; Ward 1908). In addition, as Loos (1982:134) writes, 'the whole of the fishing industry in North Queensland was suffused with the abuse of Aboriginal women', who were abducted and forced to serve as sex slaves. Aboriginal people in Cape York had no real physical or legal protection and most of the atrocities carried out on them went unreported (Blake 1998; Bottoms 2013; Frankland 1994; Loos 1982; Taylor 2003). Contemporary commentators like Walter Roth described the entire industry in far North Queensland as 'one long record of brutal cruelty, bestiality and debauchery' (Loos 1982:132).

However Aboriginal communities all along the coast mounted strong resistance (Loos 1982:118-159) and it is also true that this industry was multi-faceted; some fishers were comparatively honourable, employing and reenlisting the same people for many years (e.g. Ward 1908:131-132). However even in these instances Indigenous people were not afforded the same rights and protections as the colonial population and suffered greatly as a result (Blake 1998; Bottoms 2013; Frankland 1994; Loos 1982; Taylor 2003). Acts of resistance were often responded to with indiscriminate retribution by the fishers which frequently resulted in massacres. Furthermore, any Aboriginal person who managed to successfully repel their abductors could become a criminal in the eyes of the Queensland Government and have to contend with the police parties sent to punish them (e.g. Ward 1908:139140).

Prior to 1891, bêche-de-mer and pearl shell fishers terrorised the coastal communities around Mapoon. These intruders were responsible for deceptive recruiting, kidnapping, forced labour and massacres in response to resistance. The establishment of the mission and its opposition to the recruiters both on the ground and in print greatly affected the status quo. Nevertheless the fishers were still an ever-present threat and again, even though some of the ship masters were honourable by comparison, the majority were either treacherous or openly hostile (Hey 1931; Meston 1896; Roth 1900b, 1900c, 1901e, 1902f, 1903e, 1904b, 1905b, 1906; Ward 1908:129-148).

There is less available evidence for the Wathayn and Weipa region prior to the establishment of the second mission and enactment of the 1897 Act, however the same situation can be discerned. Meston uncovered numerous accounts of murder and kidnapping by fishers during his explorations of this region (Meston 1896, 1897a, 1897c1897i). Recording somewhere in the south east of Albatross Bay he writes 'a boat anchored there the same night took away six [Indigenous people] to work on an island in the straits. They ran away soon after arrival, swam over to the mainland, and walked back nearly 200 miles to their own home' (Meston 1896:1). On the Embley River, Meston was guided to a hidden camp on the edges of Wathayn where men, women and children were living in complete secrecy within the mangroves and harboured deep distrust of colonial people. Meston (1897f: 353) describes the rough conditions of this camp, and how some people were initially angry with his guides for 'revealing the site of their camp to a white man'.

The situation was still the same by the end of the decade even after the establishment of the Weipa mission. The actions of the bêche-de-mer and pearl shell industries were one of the factors that led to these regions being granted Aboriginal reserve statuses in an attempt to restrict their access and protect the Aboriginal communities through autocratic control (Blake 1998; Frankland 1994; Loos 1982:160-182; Roth 1900b-c, 1901e, 1902f, 1903e, 1904b, 1905b, 1906; Taylor 2003; Ward 1908). The atrocities that occurred in this region in particular are what prompted Archibald Meston (1896:13) to demand 'absolute prohibition of all aboriginal labour on pearl-shell, bêchede-mer, and tortoise-shell fishing boats under any condition whatsoever' in his recommendations for the Act. However, this demand was not realised in the 1897 Act, it was a number of years before contiguous reserve status was proclaimed for the region (see Roth 1904b) and recruiting was outlawed in the area (see Roth 1905b). By this time even more devastation and conflict had come via this frontier.

\section{The Pastoral Frontier}

Expeditions as early as the 1840 s sought to determine the pastoral viability of parts of north Queensland (Loos 1982:28-29). Pastoralists became established in the region by the 1860 s. These intruders established themselves with the assistance of the Native Police, and as Loos (1982:32) writes 'the government expected the squatters to be active partners in dispossessing the Aborigines and protecting property'. The procedure by which pastoralists took up runs was almost uniform across north Queensland. After moving into a region, pastoralists forced Indigenous people out of the area and kept them out by any means necessary (Loos 1982:33). This lead to mass dispossession, conflict, resistance and an untold loss of life (Bottoms 2013; Loos 1982:28-61). Initially Cape York however, was 'branded as a dangerous disappointment' by many pastoralists (Loos 1982:32). The Aboriginal resistance encountered on Kennedy's 1848 expedition and the 1864 Jardine brothers' expedition had not convinced run hunters that it was safe to 'scour the country ahead of settlement as they had elsewhere in North Queensland' (Loos 1982:32).

Large parts of Cape York were first intruded upon by the more fluid mining frontier (Loos 1982:62-87). In 1863, pastoralist John Jardine and company were empowered by the British and Queensland governments to establish Somerset at the tip of Cape York with the aim of developing a maritime hub that would become a Singapore of the north (Loos 1982:21; Sharp 1992:35). For this reason this settlement features heavily in the early development of Cape York's sea frontier, yet Somerset was also established with pastoral ambitions in mind and played a large part in the pastoral occupation of Cape York. John 
Jardine's sons, Frank and Alec Jardine, set out on their 1864 expedition in to reach Somerset droving 250 cattle. By the time they had arrived in 1865 with only a fraction of this livestock, members of the expedition had killed anywhere between 54 and 72 Aboriginal people on their journey through the Cape (Loos 1982:21). John Jardine was the first in a line of police magistrates to preside over the region. Frank Jardine became a Police Magistrate in 1867 (Sharp 1992:26). The initial ambitions of Somerset were short-lived, the settlement failed to attract other pastoralists and it was badly positioned for passing ships. After the government settlement moved to Thursday Island in 1877, the assets in Somerset were sold to Frank Jardine (Loos 1982:21; Sharp 1992:6). Sharp (1992:6) writes 'in Aboriginal collective memory', Somerset 'is seen as a centre of terror' where huge numbers of resisting Indigenous people were massacred and terrorised.

In the same way a large part of Cape York's sea frontier emanated from this region, so too did a part of its pastoral frontier, but in a different way. It was the construction of the Cape York telegraph line and its stations that enabled the pastoral frontier to expand throughout Cape York. Beginning in the north at Paterson Point, the line was constructed with the assistance of Frank Jardine down through the Cape between 1883 and 1887. Permanent fortified telegraph stations were set up along the line at approximately $100 \mathrm{~km}$ intervals. From north to south these were the Paterson, McDonnell and Moreton stations, though Paterson station was closed when Thursday Island was connected to the line via submarine cables. The established route of the telegraph line and the detachments of Native Police that protected it now enabled pastoralists to venture deeper into Cape York. York Downs station was established c. 1885 on the upper Mission River during the construction of the line. Merluna Station was established on the Watson River to the south in c.1888 and the Bertie Haugh Station was established on the Dulcie River to the north, also in c.1888. Subsequent to this was the establishment of Thornbury in 1891, Lockerbie in 1892 and Galloway in 1895 near Somerset in the far north (see Jack 1921b:662-677, Map A, B, C, D).

The cattle stations of Merluna, York Downs and Bertie Haugh penetrated into the country west of the telegraph line and the fortified stations of McDonnel and Moreton that supported it. Archibald Meston's explorations of the region demonstrate how the conflict of this frontier had permeated all the way through to the western coast (Meston 1896, 1897a, 1897c-i). Meston (1896:1) interviewed a large party of Indigenous people near the mouth of the Embley River, and writes that 'they told an unpleasant tale of former treatment by the native police, and at least two of them still bore the old bullet wounds'. Even in places that were multiple days travel from these stations, Meston encountered Aboriginal people who in his own words were 'hunted like wild beasts, afraid to go to sleep in their own country' (1896:3, 1897f-h). Meston's (1896:13) experiences on the pastoral frontier in this region are part of the reason why he also demanded 'the total abolition of the native police' in his recommendations for the 1897 Act.

Like the sea frontier, it is very difficult to chart the massacres and atrocities that occurred on the pastoral frontier in any part of Cape York and unfortunately as Bottoms (2013:114-132) demonstrates, a lot of what happened will forever remain unknown. Bottoms cites one recorded example from the greater Weipa area as an 'indication of how myriad smaller-scale killings took place' in the region. It was a massacre that occurred somewhere between Weipa and the Moreton Telegraph Station and was investigated by Walter Roth and Bishop Gilbert White in 1902. Their findings had concluded that a number of Aboriginal people had been attacked without warning and murdered. In addition it was clear to Roth and White that the murderers had tried to conceal what they had done by carefully removing their spent cartridges and burning the bodies of their victims (Bottoms 2013:114132).

Loos (1982:61) writes how even in the late 1890s 'liberal use of the rifle and poison to combat Aboriginal resistance was still common in Cape York Peninsula and unchecked by government policy or practice'. Loos (1982:150) demonstrates how Roth's population statistics for around 600 Aboriginal people living around the Mapoon and Weipa missions in the 1890s further highlight how these communities and their society as a whole had been deeply affected by the conflict on these frontiers. The proclamation of the Weipa and Mapoon area as a Reserve, the actions of the missionaries and the Queensland government, and the enactment of the Aboriginals Protection and Restriction of the Sale of Opium Act 1897 (Q1d) all contributed to bringing some protection to these frontiers but it was in the form of autocratic control. As Loos explains, the influence of the paternalistic bureaucracy of the government and the equally paternalistic theocracy of the missionaries came at a cost 'the price of protection, necessary though it may have been at the time, was the loss of freedom' (1982:159-182). In addition to the loss of life directly from frontier conflict, countless lives were lost through the spread of poverty, and diseases like tuberculosis, syphilis and addiction. Though coming from a single perspective, Walter Roth's official reports go some way to charting aspects of life in the Weipa and Mapoon area, year-by-year after the enactment of the 1897 Act (Roth 1900c, 1901e, 1902f, 1903e, 1904b, 1905b, 1906).

At their greatest size, the reserve lands that encompassed the Mapoon and Weipa region totalled somewhere in the region of 1.2 million acres. However after the passing of the The Comalco Act (Commonwealth Aluminium Corporation Pty. Limited Agreement Act 1957) by the Commonwealth Government in their granting of a bauxite mining lease, only 75 acres were reserved for Indigenous people. This prompted the closure of Mapoon Mission in 1963 and the relocation of its residents, and the relocation of the Weipa Mission residents (Scambary 2013:59).

While the Aboriginal societies of this region were able to maintain integral components of their pre-colonisation way of life, other facets of society had to alter, adapt, or assimilate to survive the encroachment of a colonial culture that had little tolerance for alternate ways of life and concepts of existence. However Aboriginal society, cultural identity, and collective memory prevailed through these times. A valuable resource available to interpreters of this period today is the collective traditional knowledge that Traditional Owners here are the custodians of (Ó Foghlú in press). 
Contact-Era Observations of Tool Use in Cape York

How did colonisation affect Aboriginal material culture for Cape York? In the interpretation of post-contact Cape York, it is regrettable as Loos (1982:ix) writes 'that the weight of evidence for the period ... is provided by the invading colonists'. However these sources can still provide invaluable information that can corroborate archaeological findings, expand oral histories and contribute to the sustainment of cultural identities today (Ó Foghlú in press). Focusing on observations of tool use made by explorers and ethnographers during Cape York's contact period, it is possible to gain important insights into the ways in which European colonisation affected Aboriginal material culture (Brierly 1849-1853a, 1848, 1849, 1849-1953b; Hey 1931; Huxley 1935; Jack 1921a, 1921b; Khan 1993, 1996, 2003, 2004; Leichhardt 18451846:425-464, 1847; McConnel 1939, 1940; Meston 1896, 1897a-o; Moore 1965, 1979; Moseley 1879; Robert 1973; Roth 1900b-c, 1901a-e, 1902e-f, 1903c-e, 1904a-b, 1905ab, 1906, 1907, 1908a-b, 1909a-b, 1910a-e; Schilder 1975; Sutton 2008, 2010; Ward 1908).

The development of Cape York's frontier complex sent many of the multifaceted crafts and traditions underlying this material culture into severe decline. The cataclysmic loss of over 90\% of Queensland's Indigenous population, the effects of mass deportations, and the organised efforts of missionaries (like those at Mapoon) to actively halt the continuation of cultural traditions meant that many crafts could not be passed on (Blake 1998; Bottoms 2013; Frankland 1994; Hey 1931; Khan 2003:29; Loos 1982; Ward 1908). The economy of intricate, labour intensive products like bark cloth blankets and woven mats were hard hit by the distribution of cheaply made government blankets, introduced into communities who had lost many of their experienced craftspeople (e.g. Khan 1993:35-36; Khan 2003:47-48). Other crafts, like the manufacture of certain types of traditional clothing and adornments, adapted by shifting from complex Aboriginal materials to cheaper European materials which had become more obtainable (e.g. Meston 1897f; Moseley 1879:350-365; Ward 1908:54-67).

Traditional techniques were also adapted to produce new items, like Aboriginal tobacco pipes. Artefacts collected by Roth in places like Mapoon demonstrate the innovation of local craftspeople during this period. These intricately carved bamboo pipes were equipped with interchangeable beeswax components that enabled them to be quickly adapted for personal preference or group use unlike traditional European pipes. Some of these pipes bear detailed artistic carvings of animal forms which further demonstrates the degree of complexity employed and imbued in the manufacture and use of such items (Khan 2003:50-51; Moseley 1879:350-365).

Other crafts like stone axe manufacture declined drastically as a result of resource restriction, loss of knowledge and the increased availability of European materials. However, as Roth observed, again in places like Mapoon, metal axe heads were reappropriated by Aboriginal communities and hafted with the same interchangeable handles as their stone counterparts. This enabled these tools to be reconfigured for adze or axe functions as circumstances dictated unlike European axes. In addition, because of the increased durability of iron, it was possible to use these tools far more intensively than tools made from stone (Khan 2003:52-53). Roth also noted how wood and bone harpoons were being replaced by iron harpoons manufactured with adapted techniques. Just like metal axe heads, the increased durability of these implements caused economic shifts in Aboriginal society; for instance the skill once required to hunt turtles with fragile, expensive harpoons was no longer an issue and turtle flesh went from being a delicacy to a more common food source (Khan 2003:46-47).

The construction of the telegraph line brought a major new resource into many areas. Telegraph wire was a workable, hard-wearing material that could be fashioned into fish hooks, spear prongs and other important implements. One incident near Cooktown saw over $200 \mathrm{~m}$ of the line appropriated for these needs (Wallace 2012:45). New materials from shipwrecks also became incorporated. For example while examining a number of traditional dwellings near Temple Bay (sometime between 1879 and 1880), Robert Logan Jack discovered an Aboriginal hut that had been roofed with copper-sheeting appropriated from a ship that had wrecked in the area (Wallace 2012:81).

Glass was a particularly important addition to Aboriginal material culture during the contact time. It is possible that the earliest examples of introduced glass in Cape York were regarded as interesting tokens (e.g. Loos 1982:18) however the material soon became an important resource. Roth, during his extensive ethnographic research throughout Cape York in the early twentieth century, observed how glass as a tool source could fall into three broad categories: (a) glass tools (predominately flaked examples) which replaced pre-existing stone tools and the stone components of organic composite implements (see Roth 1904a:20, 1907:394, 1909b:193, 1910b:44-45); (b) glass tools (again predominately flaked examples) which replaced pre-existing shell tools and the shell components of organic compound implements (see Roth 1901b:10, 1904a:22, 1909b:196, 1910b:44-45) and finally (c) glass that was imbued with new cultural concepts (e.g. Roth 1903c:32).

The different ways in which glass replaced stone and shell materials in Cape York are also demonstrated by Khan in her analysis of artefacts Roth collected (Kahn 1993:78, 150, 166, 2003:45, 55, 70, 2004:44, 46). For instance she describes 'a collection of 53 quartz and glass chips for spears' (catalogue number E.13886 collected by Roth in 1898) that were 'inserted in two lateral rows, in gum cement' up along the heads of quartz tipped spears. The average dimensions for these glass and stone microliths were generally $2 \mathrm{~cm}$ long, $1 \mathrm{~cm}$ wide and $0.4 \mathrm{~cm}$ thick (Kahn 1993:150). While glass cannot be ranked with iron in terms of durability, the swiftness with which a piece of glass could be rendered into a sharp implement in comparison to stone working cannot be understated. Therefore it may be the case that the introduction of glass also caused economic shifts in Aboriginal society, either for certain tool types or for the products and functions of those tools.

Most importantly, many facets of Aboriginal culture prevailed through this turbulent period and therefore the use and production of the material products and byproducts of these traditions in turn prevailed. Today, many of these traditions (like types of earth oven cooking and traditional fire-lighting) have taken on extra significance 
and new meaning, partially as a result of this survival (Ó Foghlú in press). Archaeologically, many of the same precolonisation challenges are present in the interpretation of the post-contact era. Many tools, adornments and implements were crafted from organic materials with a very poor rate of preservation. In addition many of the inorganic components of these items, like telegraph wire spear-heads, may not survive to the present-day in a form that is readily identifiable. Worked glass therefore holds great importance as a diagnostic artefact type.

\section{Indigenous Knapped Glass Artefacts in Australia}

Contact with South East Asian mariners and Europeans began a tradition of Indigenous people utilising glass (largely from bottles) in a variety of ways (Austin-Broos 2009; Birmingham and Wilson 2010; Clarke 2003; Harrison 2005; Kociumbas 2004; Macknight 1972, 1986). European bottle glass was substituted for stone as a raw material source to reproduce pre-contact stone implements. Glass artefacts replicated the function of flaked stone artefacts as implements for wood and fibre working, cutting, adzing, and for cultural purposes (Brady 2008:2; Harrison 2002, 2003:312, 2006). Glass was recognised as a source for tool manufacture early in Australian archaeological studies (McCarthy and Davidson 1943; McCarthy 1967). Since then flaked and utilised glass has been reported from many Indigenous archaeological sites from all environmental contexts across Australia where culture contact had occurred (Attenbrow 2006; Hughes and Lampert 1980; Mulvaney 2010; Smith 2006) including rockshelters, open artefact scatters, earth mounds, and shell middens in northern Australia (Akerman and Bindon 1995; Attenbrow et al. 1995; Clarke and Frederick 2011; David and Wilson 1999; Harrison 2000; Fullagar and Head 1997; McNiven et al. 1992; Mitchell 1996, 2000; O'Connor et al. 2008; Roberts et al. 1994; Ryan and Morse 2009; Sim and Wallis 2008; Sullivan et al. 2011; Ward 2004; Ward et al. 2006).

The number of knapped glass artefacts reported from the majority of these archaeological sites is generally low ranging from $<5$ to 100 items, with the exception of sites in Western Australia associated with the manufacture of Kimberley points (Akerman 1978, 2007, 2008; Akerman and Bindon 1995). Flaked glass has also been noted from sites of early Indigenous engagement with colonial outposts and settlements, historical pastoral stations, missions, mining regions, maritime economies (i.e. whaling, pearling, trepang processing), and at Indigenous town fringe settlements (Allen 1969, 2008; Beck and Somerville 2005; Birmingham and Wilson 2010; Cooper and Bowdler 1998; Gibbs and Harrison 2008; Harrison 2000, 2002, 2006, 2009; Niemoeller 1999; Niemoeller and Guse 1999). Knapped glass assemblages associated with European historical archaeological sites can be considerably high containing hundreds to thousands of worked fragments, whereas the discovery of Indigenous worked and utilised glass is rarer away from these sites of culture contact.

Holdaway and Douglas (2011:101) and Harrison (2000) acknowledge that in the past there has generally been a bias of research interest in formed flaked glass tools rather than the mundane utilised glass flakes and debitage. This situation has been the case owing to privileging typologies and from difficulties in identification of anthropogenic flaked glass debitage (Knudson 1979; Niemoeller and Guse 1999). Although the presence of glass flaked artefacts has been reported widely in archaeological assemblages, analysis of this class of artefact has improved with growing research interest in culture contact studies (Allen 1969, 2008; Akerman 1978, 2007, 2008; Akerman and Bindon 1995; Beck and Somerville 2005; Gibbs and Harrison 2008; Harrison 2003, 2006, 2009; Niemoeller 1999; Niemoeller and Guse 1999; Ulm et al. 1999, 2009; Wolski and Loy 1999). Specific studies on glass artefact technologies have concentrated on the Kimberley point with a known distribution in the north west of Western Australia into the Victoria River region of the Northern Territory with much of the literature concentrating on its emergence, production, and meaning (Akerman 1978, 2007, 2008; Akerman and Bindon 1995; Harrison 2003, 2006, 2009). In this context, Gibbs and Harrison (2008:67) state that understanding the technological production of glass tools has taken priority in archaeological research to the detriment of an understanding of the social meaning and context of glass tools. Harrison $(2002: 372,2003: 311,2006: 65)$ argues that the implications of increased production of Kimberley points (generally on glass) was stimulated not only by internal social changes but through economic engagement for trade with Europeans. Further, he states the lack of such points in archaeological contexts is a result of this European fascination and collection. Akerman (2007, $2008)$ in response to Harrison $(2003,2006,2009)$ argues strongly that the Kimberley point was very much a central part of normative and traditional Indigenous tool technology and use, and was a highly significant item in exchange practices continuing from the introduction of the serrated edge stone point c.1400 BP.

Parallel to the discussion regarding the meaning and role of glass Kimberley points, Gibbs and Harrison (2008:66) illustrate that glass artefacts from the Geraldine Mine, Western Australia represent the nature of engagement and interchange between Indigenous workers and settler economy and society. The mine subsequently became a source of raw material procurement after its abandonment as a payable mining deposit (Gibbs and Harrison 2008:66). Furthermore, Beck and Somerville (2005) document the connection between distributions of glass fragments from localities occupied historically by Indigenous people outside of townships in New South Wales and oral histories regarding Indigenous experiences. Recent archaeological studies of Indigenous mission sites highlight the significance of glass being sought out to produce flakes in the absence of iron knives rather than being indicative of alcohol consumption. Glass flakes were used for haircutting, scarring, and medical purposes and the frequent association of glass flakes with faunal remains is indicative of butchering hunted meat (Birmingham and Wilson 2010:22). Research by Ulm et al. (1999, 2009) and Wolski and Loy (1999) demonstrates the value of examining glass flakes, retouched flakes, and fragments, which have revealed a range of use wear and residues reflecting Indigenous activities during the culture-contact period. This collection of studies shows that seemingly mundane glass artefacts have proven to be significant in providing archaeological information about Indigenous technologies, mobility, and activities. 


\section{Glass Artefacts from Cape York and the Gulf of Carpentaria}

Low densities of glass flakes have been reported in rockshelters in north Queensland from the Chillagoe, Laura and Mitchell-Palmer region at Early Man Rockshelter, Sandy Creek 2 and Red Horse rockshelters (David and Wilson 1999:182-183; Morwood and Hobbs 2002:260). Small numbers of flaked glass pieces have also been noted from archaeological studies on islands in the Gulf of Carpentaria (Sim and Wallis 2008; Ulm et al. 2010). Investigations in the southern Gulf of Carpentaria region found one glass flake in an excavation of the Old Doomadgee occupation site with further surface glass fragments at the mission site (Robins et al. 1998:98).

\section{Contact-Era Observations of Tool Use in Wathayn and the Greater Weipa and Mapoon Area}

The establishment of the missions along this part of Cape York's coast meant that both the missionaries themselves (Hey 1931; Ward 1908) and visitors to the missions (e.g. Meston 1896; Parry-Okeden 1897; Urquhart 1897) were present to observe and record information during the contact period. The reports made by Roth, whose attention to detail and depth of understanding surpassed that of most of his contemporaries are of particular importance (Roth 1900b, 1900c, 1901a-e, 1902e-f, 1903c-e, 1904a-b, 1905ab, 1906, 1907, 1908a-b, 1909a-b, 1910a-e). Collectively, the corpus of ethnographic literature for Weipa during the contact period demonstrates that local Indigenous communities' material culture was complex, highly specialised and heavily reliant on organic materials (Meston 1896, 1897a, 1897c-i; Roth 1900b; Ward 1908).

Like elsewhere in Cape York, the Aboriginal people of Wathayn and the greater Weipa area employed and modified useful new materials when these became available, however, the use of many traditional tools and practices prevailed alongside these innovations. For instance, a study of culturally modified trees at Weipa revealed that more intensive 'sugarbag' (honey from native bees) harvesting occurred in areas adjacent to the mission where access to metal axes meant that they quickly replaced stone axes. However, traditional harvesting practices continued alongside these more intensive techniques (Morrison and Shepard 2013:157). While many tools and techniques used by Traditional Owners in Wathayn today are comparable to those used millennia ago, other tools and techniques have developed from such contact era innovations (Ó Foghlú in press).

The ethnographic corpus for Wathyan and the greater Weipa and Mapoon area does not reveal much about Indigenous appropriation of glass. This is unfortunate because Roth and others employed great detail in describing other aspects of this material culture, and took great care to record the use of glass in other parts of Cape York. Locally, Wathayn Traditional Owners have stated that they were unaware of any glass artefacts on archaeological sites in the region (Beatrice Gordon, pers. comm., September 2012, September 2013; Elisabeth Coconut, pers. comm., September 2012, September 2013; Graham Peinkina, pers. comm., September 2012, September 2013). Evidence of Indigenous acquisition of European materials mostly relates to gardening implements and tools exchanged in return for labour on the mission. There are other local examples of European materials replacing or augmenting traditional methods. For instance, local fishing spears were originally tipped with sting-ray barbs but now it is more often the case that short pieces of heavy steel wire are used (Napranum Cha 1987: $15,18)$. Commercial string or rope may be used as binding or 'Kuuy ngathan', a brown vine collected from the scrub (Napranum Cha 1987:18). At Wathayn, Graham Peinkina makes spears using shafts and glue from eucalypts, steel wire and commercial string (pers. comm., 11 September 2012). Much of Graham's knowledge of spear manufacture and other crafts demonstrably pre-dates the European colonisation of this region. The corpus of Traditional Knowledge held by Wathayn Traditional Owners today is extensive and a great deal can be independently corroborated with the earliest ethnographic accounts and the local archaeological record (Ó Foghlú in press). However, it is important to also study adaptations that have occurred to these traditional crafts.

While the use of wire in the making of spears may at first appear to be a modern innovation, this material has been used in the manufacture of spears in this region since the development of the telegraph line around 130 years ago. In the study of today's Indigenous material culture, care should be taken to treat every aspect with equal importance. The use of wire is an important tradition in its own right and worthy of study and protection. Just like the greater Cape York region, worked glass is an important diagnostic artefact type for the Weipa area. As will be shown below, diagnostic contact era artefacts, when found in association with Indigenous archaeological sites can address long-standing paucities in the record.

In the greater Weipa region, Shiner and Morrison (2009:52-54) note that surveys of the bauxite plateau returned a total of 1319 lithic artefacts and only one made of glass. Morrison (2010:238) in the course of his extensive work in Prunung, a beach ridge plain north of the Weipa peninsula, discovered a 'small fragment of green glass'. The glass artefact ( $13 \mathrm{~mm}$ long $\times$ 9mm wide $\times 2.6 \mathrm{~mm}$ thick) was identified with a 'series of eraillure scars running across its surface', near the base of a small shell mound site (Morrison 2010:261, 266-267). As a result, Morrison $(2010: 266,283,292)$ concludes that the artefact was 'a small flake probably produced during modification of a large piece of glass' and that its discovery so close to the basal deposits of this site, in combination with the young age of the site 'strongly supports the proposition that site formation commenced during or shortly before the late 1800 s and that it continued to be used on some basis into the post-contact period'.

Subsequently Morrison et al. (2015:93) document the presence of glass fragments in surface scatters within the various village areas defined as part of the Weipa Mission site. Glass fragments were noted to be associated with numerous built structures within the village settlement, and on a nearby complex of low earth mounds. Further study of the Weipa Mission glass assemblage may provide evidence that glass was a major economic resource highly valued for customary Indigenous use.

\section{Assessing why the Ethnographic Corpus Needs the Archaeological Record}

The majority of this region's timeline as it pertains to past societies and cultures has to be reconstructed and interpreted primarily through its archaeological record. 
This is because archaeological investigation is often the only available line of enquiry. However it has been shown that interpreters are afforded additional resources for Weipa and Mapoon's contact period, like the region's extensive ethnographic corpus. With so much information obtainable from surviving accounts contemporary to the period, why is archaeological investigation still vital in the reconstruction and interpretation of this section of Weipa and Mapoon's timeline?

In assessing the ethnographic corpus as an interpretive resource, there are positive and negative aspects that must be considered. On the positive side: the corpus can yield information about society and material culture from this period that could not survive to the present-day in artefactual form. A few examples can illustrate this: for example the first missionaries describe how local communities hunted large sea animals like dugong from canoes with tethered suckerfish. These fish were kept in captivity for a number of days so that they could be conditioned to latch onto a desired target and enable its handlers to pull the quarry to the surface so it could be dispatched (Ward 1908:121). It would be difficult for an archaeologist to independently discover evidence that this practice occurred solely through the analysis of surviving physical remains. Indeed one would be hard pressed to envisage what possible diagnostic remains could survive from this practice. While the practice itself can of course prevail through oral transmission, the actual confirmative placing of a specific act to a specific place and time can be very difficult to achieve without these surviving accounts.

Similarly, the first missionaries describe how communities made a lot of their artwork in wet earth and upon living trees (e.g. Ward 1908:104) and Roth recorded and described intricate local string art forms (colloquially referred to as cats' cradles) (e.g. Roth 1900b:14-16). Again while these artworks and art forms can of course prevail to the present day through oral and pictorial transmission, it is impossible for specific iterations to survive archaeologically. This is in stark contrast to artworks made by communities who had access to more durable mediums like extensive rock faces (e.g. Watchman 1985).

It is clear that a lot of information about Aboriginal society and culture during this period can only be obtained from resources like this ethnographic corpus. However, this does not negate the fact that this corpus contains inherent flaws that must be worked through. Colonial writings from this period cannot be considered empirical proof because they are personal observations written by fallible people with their own prejudices and flaws. Roth was the most authoritative commentator on Aboriginal society and culture in Cape York during this period and yet many of his observations were disputed during his own lifetime by other prominent Australian ethnographers. In their private correspondence Roth and Baldwin Spencer cordially express numerous disagreements with one another on a number of important issues pertaining to Aboriginal society and culture. Some of these disagreements specifically relate to perceived understandings of culture and community in Weipa (Roth 189?, 1897, 1898a-b, 1899a-c, 1900a, 1902a-d, 1903a-b; Spencer 1903).

If contemporary ethnographers with comparable expertise expressed fundamental disagreements with one another, it is therefore reasonable that their accounts are today judged not as empirical proof but as viable data that must be independently validated wherever possible. The Hitchens Razor, i.e. 'what can be asserted without evidence can also be dismissed without evidence' (Hitchens 2007:150) has been taken by modern researchers to many of these observations because of the imperfect medium through which they have been transmitted. By way of example, the anthropogenic origins of shell mounds less than $10 \mathrm{~km}$ from Wathayn have been mentioned by a number of early surveyors, geologists, ethnographers and explorers (Embley 1897a, 1897d; Jack 1921a:Map D, Map F; Jackson 1902:8, Plate II; Roth 1900b:38, 1901a:1012, 1901b:7). These observations can be dismissed by researchers when they are unable to draw substantiative evidence from other lines of enquiry (e.g. Stone 1992). This is enough to demonstrate that colonial observations are not empirical proof in their own right regardless of any merit they hold. However, because the origins of these Shell Mounds have been corroborated, refined and expanded upon by methodological, archaeological and palynological investigations (e.g. Bailey 1994; Burns 1994; Morrison 2010; Shiner et al. 2013; Stevenson et al. 2015) a more comprehensive reconstruction of the past is therefore enabled. This demonstrates how even the most seemingly self-evident information can benefit immensely from independent corroborative evidence.

\section{Absences in Wathayn's Archaeological and Ethnographic Records}

In Wathayn, it is demonstrable that Aboriginal communities' presence, society and culture have been integral components of the landscape throughout the Holocene period (Shiner et al. 2013; Stevenson et al. 2015). However, adaptations to environmental change c. 2200 years ago saw a marked reduction in discernible impact upon the landscape. Activities that brought about the rise of shell mounds, rich in diagnostic material, gave way to activities that left small, shallow mounds of earth with little or no apparent stratigraphy, artefacts or faunal remains. With the exception of shell deposits which can preserve when the quantities are large enough to affect the $\mathrm{pH}$ of the surrounding environment, all of the archaeological signatures left by the makers of these sites are very similar to those left by natural phenomena. For instance the traces of intensive human engineered burning are similar to the detectable traces of natural bush fires that occurred concurrently throughout the development of these sites. Also, due to the paucity of readily available utilitarian stone sources, the majority of tools, adornments and implements throughout this period were crafted from organic materials with a poor rate of preservation in the wet-dry tropics. Furthermore, the inorganic artefact types that can survive in abundance, like termite mound clay heat retainers, are almost identical to the by-products of natural processes (Embley 1896, 1897a-d; Khan 2004:97-106; Napranum Cha 1986:1-10, 1987:15-18; Ó Foghlú in press; Roth 1900b). There is a distinct lack of diagnostic artefacts associated with this site type.

Earth mounds as a site type, in contrast to shell mounds, can also be difficult to distinguish from the surrounding landscape or from natural features like collapsed termite mounds and megapode mounds (Megapodius reinwardt). The traces of the communities who created one of the most abundant site types in Wathayn are therefore almost 
invisible, and this invisibility extends throughout the contact period (Ó Foghlú in press). X-ray diffraction, a range of soil and magnetic analyses and experimental archaeology, coupled with new ethnoarchaeological research have all contributed to reveal the complexity and sustainability of these anthropogenic sites throughout the last two millennia in Wathayn (Ó Foghlú in press). However one key problem to understanding how these sites were utilised during the contact period, is the ability to tie them to this period. This is in part due to a distinct lack of diagnostic contact era artefacts and the ability to reliably date recent contexts through traditional archaeological methods (Ó Foghlú in press).

There are two paucities in the ethnographic corpus for Wathayn and the greater Weipa area that are of particular importance to the interpretation of this archaeological record. As will be shown below (see Discussion), while these paucities may at first appear trivial in the greater historical picture of the contact-era, their analysis addresses subjects that are integral to social and cultural identities and collective memory today (Ó Foghlú in press). The first, as already covered, is the absence of local Aboriginal communities' use of glass as a tool source. Despite the great detail employed by Roth and others in describing the use of glass in other parts of Cape York during the contact period; the ethnographic record for this region reveals almost nothing about how local Aboriginal craftspeople adapted to the introduction of this material. The second paucity is the absence of earth mound descriptions. Despite being a common site type all over Weipa there is no obvious mention of any earth mound sites in the ethnographic corpus for the region. This is particularly disappointing for Wathayn because John T. Embley, surveyed the area extensively prior to the establishment of the Weipa Mission. Embley's reports, which can be corroborated with modern Lidar data, show that he made numerous transects all across Wathayn, including the Diingwulung area which is dominated almost exclusively by earth mounds. He does not record any details for these sites however, or for the larger Shell Mound sites in western Wathayn even though many of these would have been prominent in the landscape (Embley 1896, 1897a-e; Geoff Wharton, pers. comm., October 2015; Jack 1921b:631-661, Map B, C, D; Ó Foghlú in press; Urquhart 1897).

The closest contact-era description of an earth mound site is possibly that of Henry Nottidge Moseley, who visited Somerset to the north in September 1874. Moseley's description of this slight, irregularly oval mound and its utilisation by the persecuted Aboriginal communities in Somerset is unique for the region. This is because he also includes descriptions of termite mounds, megapode mounds, burial mounds, long house constructions and 'kitchen-middens', (a term he uses interchangeably with 'shell mounds') in the same account. This is an instance where an earth mound site is described in the same pages as many of the anthropogenic and natural features they are often confused with (Moseley 1879:147, 273, 350-365; Ó Foghlú in press).

Therefore in Wathayn, there is a paucity of information pertaining to the utilisation of one of the area's most abundant archaeological site types during the contact period. There is also a paucity of information pertaining to the use of an important, diagnostic artefact for this same period. Furthermore there is a paucity of information in the local ethnographic corpus about these same issues, and Traditional Owners in Wathayn today are unaware of any complementary information. While the greater ethnographic corpus for Cape York as a whole provides a great deal of viable data that can help to address these issues, they still require independent archaeological corroboration wherever possible. As will be shown below (see Discussion) this validation is not just necessary for expanding the archaeological record for Wathayn's past, but is equally important for Wathayn's Traditional Owners who are part of its present.

\section{Methodology for Identification of Modified Glass}

Gibbs and Harrison (2008:61) state that there have been numerous studies on establishing the validity of Indigenous knapped glass artefacts in Australia which has been overwhelmingly achieved. Much of the original work on the identification of Indigenous modified glass in Australia was pioneered by Allen (1969; 2008) and Allen and Jones (1980) who ascertained methods of glass bottle reduction from his study of glass artefacts from the colonial settlement of Port Essington in the Northern Territory and at the Oyster Cove midden in Tasmania. Authenticating Indigenous glass artefacts has been acknowledged to have methodological difficulties owing to the natural conchoidal fracturing properties of glass and that discarded broken pieces of glass can exhibit flake scars through trampling (Allen and Jones 1980; Gibbs and Harrison 2008; Knudson 1979; Niemoeller and Guse 1999). Allen and Jones (1980:231) particularly emphasised the need for the presence of 'struck flakes with bulbs of percussion also emerged as a valuable possible indicator of Aboriginal modification' as well as 'bifacial versus internal and external unifacial flaking' on the bottle glass walls. Harrison (2000) contributed significantly to standardising the methodological approach to recording glass flaking technology by combining this with well-established stone flaking identification methods (see Andrefsky 2005; Hiscock 1984).

This study utilises Harrison's (2000) classification of glass bottle characteristics and features which are important in knapped glass identification such as the shoulder, base and sides. Harrison (2000) concluded in his study that Indigenous knappers' indicated preferences for particular sections of glass bottles. Identification of an Indigenous glass artefact typically relies on careful methodological identification to identify attributes as defined by Andrefsky (2005) such as negative flake scars, bulb of percussion, point of force application, platform, and errailure scar and ripple marks. Numerous studies have shown that other characteristics for identifying anthropogenic origin for knapped glass are typically unidirectional flake scars, minimal multidirectional negative scarring or breaks, and the selection of bottle fragments (Allen and Jones 1980; Harrison 2000, 2005; Niemoeller and Guse 1999; Ulm et al. 2009). Modification through post depositional processes such as trampling generally produces multidirectional scars on any given platform surface unlike those found on anthropogenic knapped and utilised glass artefacts. Microwear, or usewear, has been researched in great detail for lithic artefacts and is defined as a series of scarring along edges of an artefact during intentional use and can be commonly 
detected through high resolution microscopy (see Andrefsky 2005:5-7; Fullagar 2006:221). Context is also a recurrent methodological theme in the identification of Indigenous flaked glass to rule out other taphonomic factors such as trampling, crushing, and other modern impacts (Allen and Jones 1980; Harrison 2000, 2005; Niemoeller and Guse 1999; Ulm et al. 1999, 2009).

\section{The Glass Artefact and Site Context}

The Diingwulung 32 and 33 earth mounds are located in a part of Wathayn known to Traditional Owners as Diingwulung (Figure 1). This area is an archaeologically rich landscape with at least 51 identified earth mound sites, of at least two different varieties (Ó Foghlú in press), utilised from about 500 years ago until recently (Brockwell et al. in press).

The earth mounds are known to contain archaeological features such as earth ovens, termite mound clay heat retainers, stone artefacts, and faunal remains (Polymesoda erosa) (Ó Foghlú in press).

High densities of shell mounds occur as clusters approximately $6 \mathrm{~km}$ to the west of Diingwulung in western Wathayn. Post-contact, Morrison et al. (2010:89) and Shiner and Morrison (2009:54) demonstrate continuity of Indigenous resource management and land-use in the region following the establishment of the Weipa Mission in 1898 (Spring Creek Site 1898-1932; Jessica Point Site 1932-1966). From multiple cultural heritage surveys, there have been just under a thousand culturally modified trees (CMT) recorded in the Weipa landscape illustrating the continuity of Indigenous extraction of 'sugarbag' from the Cooktown ironwood (Erythropleum chlorostachys) (Morrison et al. 2010:100; Morrison and Shepard 2013). The Diingwulung area is one of the closest named resource localities to the west of the Spring Creek mission site that was occupied between 1898 and 1932 (Morrison et al. 2010:96).

Diingwulung, meaning 'my home' (Beatrice Gordon, pers. comm. September 2013), is located on Wathayn Country and is a place of immense cultural and social significance to its Traditional Owners and Naprunam residents. It has been an important camp site for many generations of people and was the site of an outstation that was destroyed by fire in the 1990s. The area is also known by the name of 'Running Creek' for its reliable drinking water supply from springs associated with a permanent creek. Diingwulung is also recognised for its resources, including feral pigs, wallabies, medicinal plants, shellfish, yams and 'sugarbag'. Historically, Diingwulung is associated with the post-contact period when the Weipa mission cattle industry was established and with the Aboriginal stockmen who worked for the mission. The first section of the Diingwulung stockyards was built in the 1930s for mustering cattle with a second yard and plunge dip built in the 1970s. Therefore there is a strong established link between Indigenous Traditional Owners and the Diingwulung area that continues from pre-contact times and throughout the mission, pastoral and mining eras up until the present day.

The Diingwulung 32 and 33 earth mounds lie together near water on a western slope towards one of the Diingwulung creeks. In selecting earth mounds for analysis, preservation is one of the main determinants that affect site choice. Owing to their soft matrices and shallow profile, earth mounds can become heavily disturbed by bioturbative floral growth and a number of native goanna species. Additionally invasive species like feral pigs (Sus scrofa) can destroy sites through digging. Other determinates include site location, in terms of relationship to other sites under investigation, and the time constraints of fieldwork.

In addition to their unique pairing, the Diingwulung 32 and 33 earth mounds exhibited a very low level of disturbance. Both were surveyed and mapped in detail. Of this pair, only Diingwulung 33 was selected for excavation due to the time constraints of fieldwork. A number of earth mound sites were excavated in Diingwulung and western Wathayn. Detailed analysis, including X-Ray Diffraction (XRD), a range of soil and magnetic analyses, artefactual analysis and experimental archaeology coupled with new ethnoarchaeology indicates that these sites formed from intense anthropogenic activity that involved the construction of earth ovens, human engineered fires and a number of associated resource processing uses (Ó Foghlú in press).

At least 51 earth mound sites have been identified in this area. Diingwulung 32 is $12.8 \mathrm{~m}$ by $11.3 \mathrm{~m}$ with a height of $0.5 \mathrm{~m}$, while Diingwulung 33 is $12.5 \mathrm{~m}$ by $10 \mathrm{~m}$ with a height of $0.7 \mathrm{~m}$. Stone artefact assemblages were noted on the surfaces of both sites and more stone artefacts were discovered throughout the excavation of Diingwulung 33 (Ó Foghlú in press). The Diingwulung 32 glass artefact was discovered while carrying out a detailed surface description of that site (Figures 2-3). The artefact was lying within, and partially obscured by, the uncompacted surface soil near the highest point of the site.

According to Harrison's (2000) bottle identification methodology the Diingwulung 32 earth mound glass artefact is a fragment of glass from the shoulder of a bottle where widening occurs at the join to the bottle neck, hence the curvature of the glass artefact (Figure 4). The surface of the artefact is characteristic of moulded glass and is a light green colour. The thickness of the glass is variable from $6.2 \mathrm{~mm}$ to $5.1 \mathrm{~mm}$ indicating non-machine method of production (Hutchinson 1987; Jones and Sullivan 1985). After 1903 machines were able to control thickness of glass and make bottles that were more highly uniform than those made from hand blown moulds (Jones and Sullivan 1985:171). There are a number of minor impurities and bubbles visible in the glass with a large piece of an intrusive substance, consistent with the glass mix being fired too slowly; which is typical of cheap glass bottle production during the colonial era (Hutchinson 1987:159). Altogether, assessing the colour, characteristics, and imperfections of the glass and its fabric, the fragment most likely derives from a mid-to-late nineteenth century handblown mould bottle (Jones and Sullivan 1985).

At first order Indigenous flaked artefact classification, the glass fragment is a core exhibiting multiple flake scars. The majority of the struck negative flake scars are initiated from a single platform on the outer convex surface of the bottle fragment (Figure 4). Positive identification of this glass fragment as an Indigenous utilised artefact also includes the radial scars illustrating the initiation of unidirectional force where it has been applied multiple times. The maximum dimensions of the artefact are $24.71 \mathrm{~mm}$ (length) $\mathrm{x} \quad 22.16 \mathrm{~mm}$ (width) $\times \quad 6.37 \mathrm{~mm}$ (thickness). It weighs $6 \mathrm{~g}$ (Figure 4). 


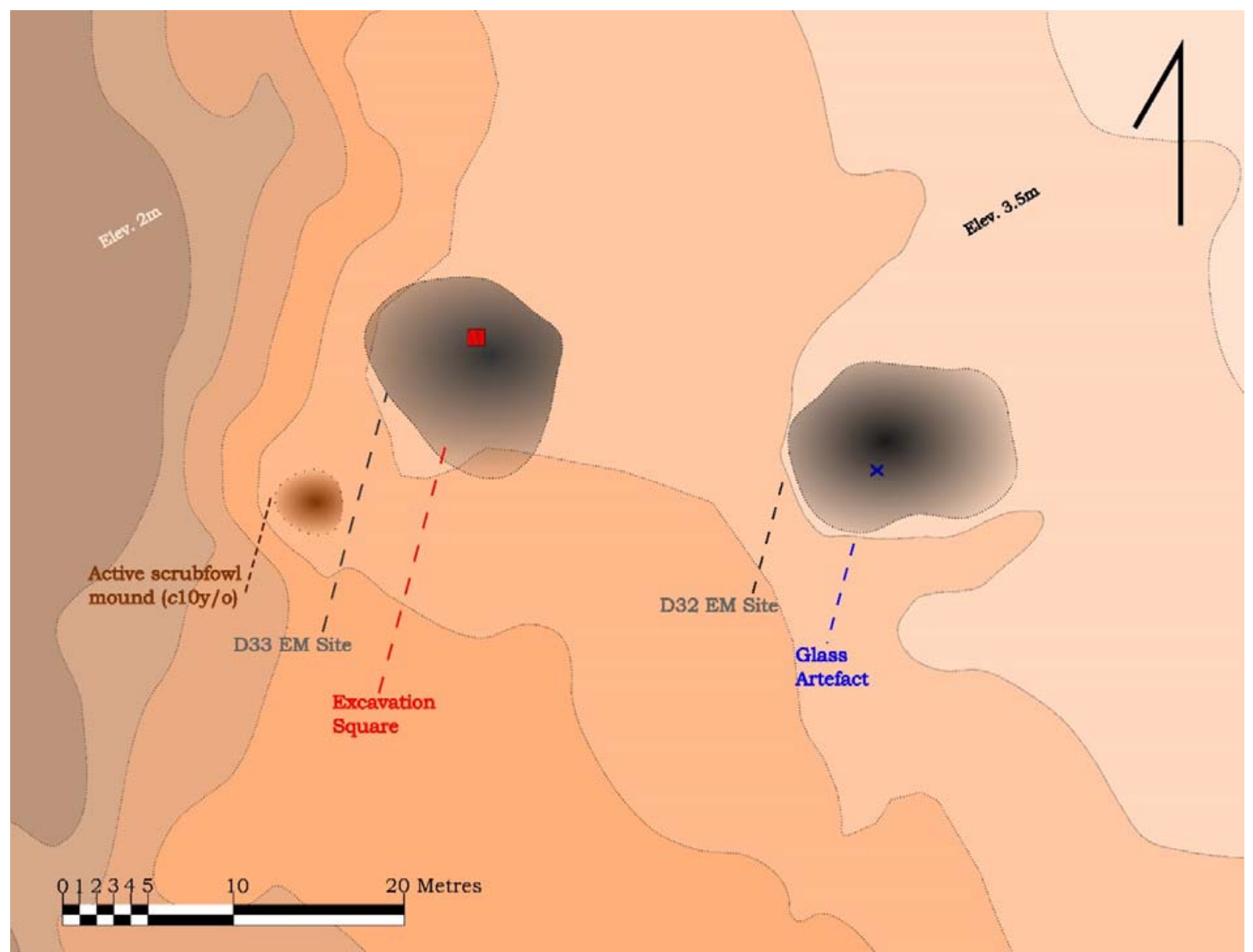

Figure 2. Diingwulung Site Map (Billy Ó Foghlú).

\begin{tabular}{|l|l|l|}
\hline & D33 EM Site & D32 EM Site \\
\hline
\end{tabular}

Figure 3. Diingwulung Site Elevation (Billy Ó Foghlú). 


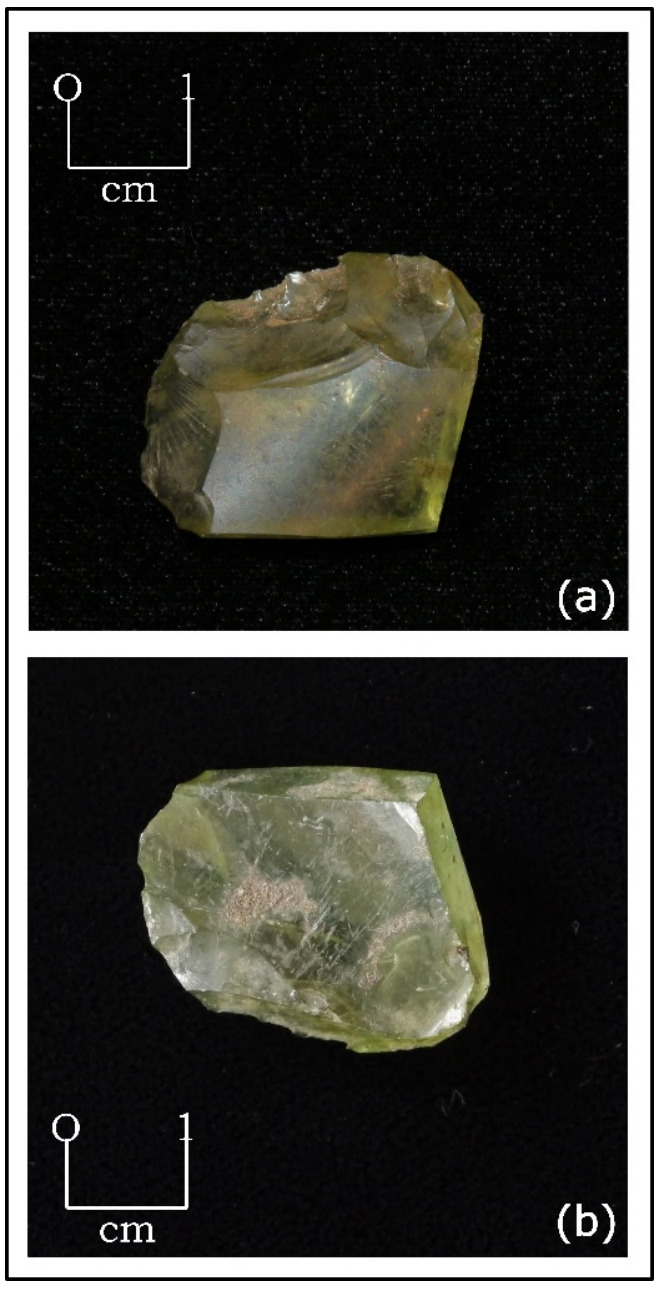

Figure 4. Illustrating (a) convex and (b) concave surfaces from the original glass bottle source (Daryl Wesley).
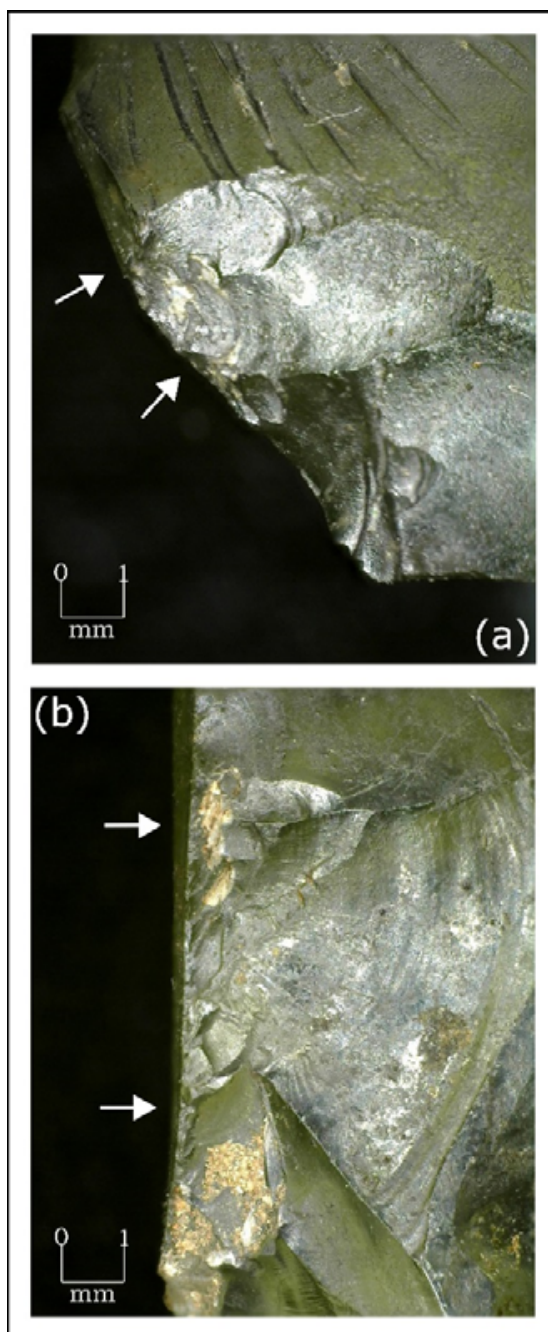

Figure 5. Arrows indicative of microwear along flaked edges of the glass artefact (Daryl Wesley).

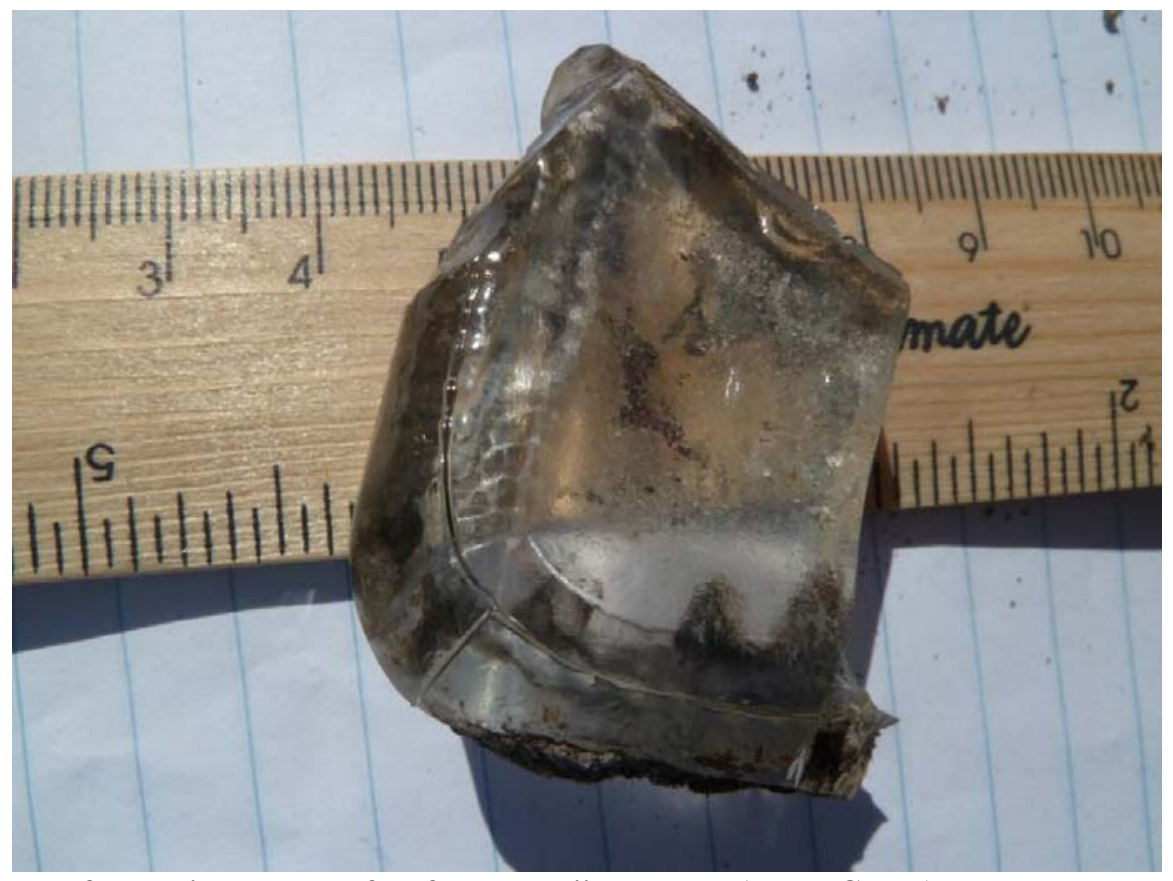

Figure 6. Example of potential glass artefact found at Diingwulung (Helen Cooke). 
From this platform, a sequence was started with the removal of several primary flakes to create the main scar with at least nine layers of sequential negative flake scars on this outer section all in a uniform direction. Furthermore, at 200x magnification four utilised edges on this glass fragment were identified where micro-size glass flakes have fractured away from the edge. The edges with the identified microwear are (a) $7.32 \mathrm{~mm}$, (b) 13.03 , (c) $5.1 \mathrm{~mm}$ and (d) $5.61 \mathrm{~mm}$ in length demonstrating intended use of specific edges of the glass fragment. Two of these edges are illustrated in Figure 5. Unidirectional deep scratches on the sides of the artefact are also indicative of a commonality in the use-wear process. Microwear on these four edges show hertzian and bending initiations, wide negative flake scars, and step terminations. The microwear is created from purposeful unidirectional initiation and impacts from these platform edges. Examining the edges at 200x magnification shows sand and silt grains embedded in some places of the negative flake scars with a red coloured residue.

Taphonomic aspects of post-deposition wear suggest that the glass artefact has been in an archaeological context for a long period of time with pitting and scratches on the surface. The haphazard nature of the scratches is more likely to be indicative of taphonomic wear of the artefact rather than when it was part of the original bottle. If the artefact had been subjected to trampling, it should have multidirectional flake scars and edge damage. The glass fragment clearly demonstrates unidirectional flake initiation and microwear typical of a utilised artefact.

\section{Discussion}

There are several areas of discussion that arise from the Diingwulung 32 glass artefact regarding its use, its age and what it can tell us about Indigenous life in Wathayn in the contact era. The presence of a single utilised flaked piece of glass on an Earth Mound site can help corroborate viable data of the ethnographic corpus with the archaeological record for Wathayn and the greater Weipa area. It is not simply indicative of a point of culture contact between Indigenous people and Europeans in the Weipa region (Russell 2001) but an example of the continuity of traditional ecological knowledge and resource extraction methods that appears to be commonplace across western Cape Aboriginal mission sites (Dalley and Memmott 2010; Morrison et al. 2010).

Weipa also has other distinctive evidence to demonstrate the significance and extent of post-contact regional mobility and land-use such as culturally modified trees (Morrison and Shepard 2013). However, the presence of a small utilised glass artefact can complement this record because it comes from a different line of enquiry. The Diingwulung 32 artefact demonstrates evidence of systematic use with evidence of bending flake scars and multiple flake scars to form four distinctive working edges. The scars along the longest edge are consistent with a typical range of hard wood processing activities, perhaps woodworking (see Ulm et al. 2009). Roth details extensive observations and made significant collections of wooden and fibre materials produced by Cape York communities (Khan 1993, 1996, 2003, 2004). His evidence suggests that the other edges of the glass artefact could have been utilised for processing plants and fibres, or inscribing cultural materials with designs (Roth 1901c:10, 1903c:32, 1904a:20, 22, 1907:394, 1909b:193,196, 1910b:44-45). Morrison (2010:267) attributes the glass flake recovered from a Shell Mound at Prunung to the late nineteenth century. Analysis of our glass artefact suggests a similar date in the late nineteenth century when Weipa became part of the maritime and pastoral frontiers within the greater contact complex of Cape York.

One can speculate as to whether this artefact was discarded at Diingwulung 32 before or after the establishment of the mission in Weipa. It has been shown how the Aboriginal communities of Weipa were experiencing multiple stages of colonial contact simultaneously throughout this time. The contact-era did not begin with the establishment of the mission, however the Diingwulung area is one of the closest resource localities to the west of the mission site (Morrison et al. 2010:96). The association of this artefact with an earth mound site is important because it corroborates ethnographic accounts from other areas that show how earth mound utilisation and reutilisation continued into the contact era (Ó Foghlú in press; see Rosendahl 2012:136, $143,149-150$ for mound use on Mornington Island into the contact period). According to Morrison et al. (2010:87), during the early phase of their establishment, many Aboriginal missions in northern Queensland were poorly resourced and therefore 'customary Indigenous forms of production such as gathering, hunting, and fishing' were necessary to sustain the Indigenous population. Although Morrison et al. (2010) concentrate on times of economic hardship at the Weipa Mission post-1932 and analyse Indigenous resource procurement accordingly in this context, the find of a dateable glass piece at Diingwulung 32 suggests similar resource utilisation practices were occurring in the Diingwulung area during the early and premission phases.

There is also the issue of the paucity of utilised glass artefacts found at Indigenous sites on the Weipa Peninsula despite strong evidence of post-contact Indigenous mobility, land-use and production of material culture (Hey 1931; Khan 2004:97-106; Meston 1896, 1897a-i; Morrison et al. 2010, 2015; Roth 1900b; Ward 1908). In other historical settlement contexts the uptake of glass as a resource was significant, as has been demonstrated by Morrison et al. (2015) at the local Weipa Mission (see Allen 1969, 2008; Beck and Somerville 2005; Birmingham and Wilson 2010; Cooper and Bowdler 1998; Gibbs and Harrison 2008; Harrison 2000, 2002, 2006, 2009; Niemoeller 1999; Niemoeller and Guse 1999). Observations by one of us (HC) suggest that there are more examples at Weipa, particularly at Diingwulung, that are worthy of further study (Figure 6).

Furthermore the presence of a single utilised flaked piece of glass on an earth mound site in Wathayn holds importance for Traditional Owners today. Olick (2008:7) writes how the difference between history and collective memory is not a difference between public and private, but is based on the relevance of the past to the present. History can be viewed as a remembered past which we no longer have an organic connection to, whereas collective memory is an active past that we are connected to in the present, a past that contributes to the formation of our identities (Olick and Robbins 1998:111). Collective, or social, memory is a connective structure, whereby remembering individuals remember together, in forms and processes like 
commemoration, monument building, tradition, myth and identity (Olick and Robbins 1998:105-106). Therefore the various themes of history, colonial observation, Indigenous ethnography, and archaeology become combined to create an interconnected narrative that has been played out through the discovery of this glass artefact from Diingwulung 32. Assmann (1997:9; see also Olick 2008:8) uses the term 'mnemohistory', to encapsulate the active process of meaning-making through time. Mnemohistory pertains not to the original significance of past events, but how these events are regarded in the present (Tamm 2015: 4), how we position ourselves and are positioned by the narratives of this past (Olick and Robbins 1998:122). Communities are constituted by their past, in many ways a real community is a community of memory (Olick 2007:20).

Identities, both individual and collective are 'established and maintained through a variety of mnemonic sites, practices and forms' (Olick and Robbins 1998:124). One of the factors that brings the individualist aspects of memory to the collective level is that 'there are mnemonic technologies other than the brain' (Olick 1999:342). Olick (1999:342) cites an example of an individual writing a note or taking a photograph as extending the capacity to remember outside the individual mind, in what can be called a 'prosthetic memory'. Olick (1999:343) explains how 'perhaps the clearest demonstration of the genuinely collective nature of remembering is the degree to which it takes place in and through language, narrative and dialogue', saying language in particular 'is a quintessential example of a supra-individual phenomenon'.

Archaeology deals primarily with material forms of memory (i.e. the recovery of lost, or perhaps forgotten external memories) (Olick 1999, 2007; Olick and Robbins 1998:112-113). This takes us to Assmann's modes of memory. Defined as (1) mimetic memory: the transmission of practical knowledge from the past, (2) material memory: the history contained in objects, (3) communicative memory: the residues of the past in language and communication, and finally (4) cultural memory: the transmission of meanings from the past (Assmann 1992; see also Olick and Robbins 1998:111-112). For Traditional Owners in Wathayn the contact era is part of collective memory and mnemohistory and part of Wathayn. Wathayn is Country; not just a physical place, but a landscape concept that is embedded within ways of living and being. Monchamp (2014: 135) explains how for Aboriginal communities Country can be a collective of human and non-human actors, where location, people and meanings are combined and 'Relationships to Country are manifold and intrinsic to people's identities and ways of being in the world'. On a local level, the discovery of a diagnostic contact-era artefact on an earth mound site meant a great deal to Traditional Owners. They were surprised and happy that this artefact had been found, because they had never seen an artefact like this in Diingwulung before (Beatrice Gordon, pers. comm., September 2012, September 2013; Elisabeth Coconut, pers. comm., September 2012, September 2013; Graham Peinkina, pers. comm., September 2012, September 2013). Many stone tools dot this area, including large adz/axe heads, and while the Traditional Owners know a lot of information about many of these pieces from their oral history, they represent important relics of a somewhat distant past. While glass tools are also a relic of previous generations, they represent a different connection to living memories and a more immediate time.

Being able to suggest post-contact utilisation (or reutilisation) of an earth mound site was also very important. The broader results of archaeological investigations in Wathayn have been able to demonstrate to the people of Wathayn that some practices and traditions, which are part of their cultural identity today; have been part of this landscape for millennia (Ó Foghlú in press). It is important to note that the discovery of a glass artefact was not regarded as 'new' information to Traditional Owners in Wathayn, nor was the knowledge that an Earth Mound site was being utilised in the recent past in Diingwulung. The Traditional Owners already suspected, that like other parts of Cape York, there was a reasonable likelihood that people would have availed of glass as a tool source in Wathayn during the contact time. However, it still meant a great deal to know it could be confirmed, seen and touched through this line of enquiry (Beatrice Gordon, pers. comm., September 2012, September 2013; Elisabeth Coconut, pers. comm., September 2012, September 2013; Graham Peinkina, pers. comm., September 2012, September 2013). Wathayn is an archive of material memory. Being able to contribute not just to the history, but mnemohistory of Wathayn means that archaeological investigation can also contribute to a recent past with which Traditional Owners still have an organic connection with; a past that is part of collective memory today, and a shaper of cultural identity.

\section{Conclusion}

The regions of Wathayn and the greater Weipa area became part of the maritime and pastoral frontiers within Cape York's contact complex during the mid-to-late nineteenth century. This period was very turbulent for local Aboriginal communities. Many aspects of Aboriginal society had to alter, adapt or assimilate to survive the encroachment of a colonial culture that had little tolerance for alternate ways of life and concepts of existence. However many other aspects of Aboriginal society, cultural identity and collective memory prevailed through these times. Morrison et al. (2010) and Morrison and Shepard (2013) have shown that extracting 'sugarbag' from ironwood continued to be a common practice at Weipa after the establishment of the mission in 1898. Just as Ulm et al. (2009:117) demonstrate in their study of glass artefacts from Bustard Bay, Queensland, the utilisation of glass at Weipa similarly demonstrates 'historical continuities in the use of, and transmission of knowledge about, culturally important places' and plant processing and wood-working activities. Likewise, the Diingwulung 32 glass artefact enables us to confirm continuity of occupation and the importance of the Diingwulung earth mound sites in post-contact times, from an archaeological line of enquiry. Even seemingly self-evident information can benefit immensely from independent corroborative evidence.

This echoes the logic of Bradley (1993) and Holtorf (1998) presented in the introduction that the latter use or reuse of an archaeological site is as important as its original function or purpose in interpreting the entire life history of a site. Whether this means the Diingwulung earth mounds were reutilised in new ways, or their purpose was an exact 
continuation of their pre-contact role, this artefact also allows us to contribute information about the life histories of these sites and the people who developed and utilised them. Similarly the glass artefact highlights a reutilisation of a pre-contact technology on a post-contact material that enables us to date this specific activity (i.e. late nineteenth century). It has also been shown how this artefact and its context can contribute positively to Wathayn's mnemohistory and the collective memory of Traditional Owners today. Wathayn is an archive of material memory, not just a static location but a landscape concept embedded within ways of living and being. Most importantly, the Diingwulung 32 glass artefact highlights how significant even one piece of glass can be in interpreting sites that often require elaborate analytical techniques to discern even minor aspects of their past development and utilisation (Ó Foghlú in press).

\section{Acknowledgements}

Fieldwork was undertaken by Billy Ó Foghlú, Dr Sally Brockwell and Helen Cooke. It was supported by the ARC-funded Linkage Project Enhancing Cultural Heritage Management for Mining Operations: A Multi-Disciplinary Approach (LP110100180) with Industry Partner Rio Tinto Alcan, and the ARC-funded Discovery Project Earth Mounds in Northern Australia: Archaeological and Environmental Archives of the Mid to Late Holocene (DP120100512). The authors would like to thank Wathayn Traditional Owners, Beatrice Gordon, Elisabeth Coconut, Graham Peinkina; Rocky Madua and Jason Wipa for their valuable support, guidance and assistance throughout the fieldwork seasons from 2011 to 2013. Dr Jack Fenner (Australian National University) contributed significantly with mapping and surveying, Dr Justin Shiner and Rio Tinto Alcan cultural heritage management staff supported us greatly by facilitating the fieldwork. The authors would also like to thank Kristie Martin for proof-reading and copy-editing the manuscript.

\section{References}

Akerman, K. 1978 Notes on the Kimberley stone tipped spear, focussing on the point hafting mechanism. Mankind 11:486489.

Akerman, K. 2007 Discussion: On Kimberley points and the politics of enchantment. Current Anthropology 48(1):133.

Akerman, K. 2008 'Missing the point' or 'What to Believe' - The theory or the data: Rationales for the production of Kimberley points. Australian Aboriginal Studies 2:70-79.

Akerman, K. and P. Bindon 1995 Dentate and related stone biface points from Northern Australia. The Beagle: Records of the Museums and Art Galleries of the Northern Territory 12:8999.

Allen, J. 1969 Archaeology and the History of Port Essington. Unpublished $\mathrm{PhD}$ thesis, Australian National University, Canberra.

Allen J. 2008 Port Essington: The Historical Archaeology of a North Australian Nineteenth Century Military Outpost. Studies in Australasian Historical Archaeology 1. Sydney: University of Sydney Press.

Allen, J. and R. Jones 1980 Oyster Cove: Archaeological traces of the last Tasmanians and notes on the criteria for the authentication of flaked glass artefacts. Papers and Proceedings of the Royal Society of Tasmania 114:225-233.

Andrefsky, W. 2005 Lithics: Macroscopic Approaches to Analysis. Cambridge: Cambridge University Press.
Anon. 1894a The Kanahooka Disaster: The Missing Boat's Crew Found. A Terrible Tale of the Wilds. In Contact with Blacks. Saved by Missionaries Influence. [By Telegraph]. Barrier Miner 9 February.

Anon. 1894b The Kanahooka Wreck. Safety of the Second Boat. Eight Men Rescued. Names of Survivors. Particulars of the Wreck. The Donkeyman's Story [By Electric Telegraph]. The Brisbane Courier 9 February.

Assmann, J. 1992 Das kulturelle Gedächtnis: Schrift, Erinnerung und politische Identität in frühen Hochkulturen. Munich: $\mathrm{CH}$ Beck.

Assmann, J. 1997 Moses the Egyptian: The Memory of Egypt in Western Monotheism. Cambridge: Harvard University Press.

Attenbrow, V. 2006 What's Changing: Population Size or Land Use Patterns? The Archaeology of Upper Mangrove Creek, Sydney Basin. Terra Australis 21. Canberra: ANU E Press.

Attenbrow, V., B. David and J. Flood 1995 Mennge-Ya and the origins of points: New insights into the appearance of points in the semi-arid zone of the Northern Territory. Archaeology in Oceania 30(3):105-120.

Austin-Broos, D.J. 2009 Arrernte Present, Arrernte Past: Invasion, Violence, and Imagination in Indigenous Central Australia. Chicago: University of Chicago Press.

Bailey, G. 1975 The Role of Shell Middens in Prehistoric Economies. Unpublished $\mathrm{PhD}$ thesis, University of Cambridge, Cambridge.

Bailey, G. 1977 Shell mounds, shell middens and raised beaches in the Cape York Peninsula. Mankind 11:132-143.

Bailey, G.N. 1994 The Weipa shell mounds: Natural or cultural? In M. Sullivan, S. Brockwell and A. Webb (eds), Archaeology in the North: Proceedings of the 1993 Australian Archaeological Association Conference, pp.107-129. Darwin: North Australian Research Unit, Australian National University.

Bailey, G.N. 1999 Shell mounds and coastal archaeology in northern Queensland. In J. Hall and I.J. McNiven (eds), Australian Coastal Archaeology, pp.105-112. Research Papers in Archaeology and Natural History 31. Canberra: ANH Publications, Department of Archaeology and Natural History, Research School of Pacific and Asian Studies, Australian National University.

Bailey, G.N., J. Chappell and R. Cribb 1994 The origin of Anadara shell mounds at Weipa, North Queensland. Archaeology in Oceania 29(2):69-80.

Barham, A. 2000 Late Holocene maritime societies in the Torres Strait Islands, northern Australia - Cultural arrival or cultural emergence? In S. O'Connor and P. Veth (eds), East of Wallace's Line: Studies of Past and Present Maritime Cultures of the Indo-Pacific Region, pp.223-314. Rotterdam: A.A. Balkema.

Beck, W. and M. Somerville 2005 Conversations between disciplines: Historical archaeology and oral history at Yarrawarra. World Archaeology 37(3):468-483.

Birmingham, J. and A. Wilson 2010 Archaeologies of cultural interaction: Wybalenna Settlement and Killalpaninna Mission. International Journal of Historical Archaeology 14(1):15-38.

Blair, S and N. Hall 2013 Travelling the 'Malay Road': Recognising the heritage significance of the Macassan maritime trade route. In M. Clark and S. May (eds), Macassan History and Heritage: Journeys, Encounters and Influences, pp.205-226. Canberra: Australian National University Press. 
Blake, T. 1998 Deported ... At the sweet will of the government: The removal of Aborigines to reserves in Queensland 18971939. Aboriginal History 22:51-61.

Bottoms, T. 2013 Conspiracy of Silence: Queensland's Frontier Killing Times. Sydney: Allen \& Unwin.

Bradley, R. 1993 Altering the Earth: The Origins of Monuments in Britain and Continental Europe. Edinburgh: Society of Antiquaries of Scotland.

Brady, M. 2008 First Taste: How Indigenous Australians Learned About Grog, Book 4: The Story of the Bottle. Canberra: National Library of Australia.

Brierly, O. 1848 Islands, Torres Straits / Sketches by O.W. Brierly [Microfilm CY 2964], Mitchell Library, Sydney.

Brierly, O. 1849 H.M.S. Rattlesnake. Sketches - Cape York, New Guinea, Torres Straits, Louisiades, Sep. to Dec. 1849 [Microfilm CY 868 (PXA 510)], Mitchell Library, Sydney.

Brierly, O. 1849-1853a, Oswald W.B. Brierly - Journal Onboard H.M.S. Rattlesnake, mainly Oct. - Nov. 1849 [Microfilm MAV/FM4/2560 (A 509)], Mitchell Library, Sydney.

Brierly, O. 1849-1853b Oswald W.B. Brierly: H.M.S. Rattlesnake: Passage to England, 1849-1853 [Microfilm - CY 104 (PXA 521], Mitchell Library, Sydney.

Brockwell, S. 2006 Earth mounds in northern Australia: A review. Australian Archaeology 63:47-56.

Brockwell, S., B. Ó Foghlú, J. Fenner, J. Stevenson, U. Proske and J. Shiner in press New dates for earth mounds at Weipa, north Queensland, Australia. Archaeology in Oceania.

Burns, T. 1994 Mound over Matter: Origins of Shell and Earth Mounds of Northern Australia; An Evaluation of Mounds on Channel Island and Middle Arm Mainland, Darwin Harbour. Unpublished $\mathrm{PhD}$ thesis, Department of Anthropology Northern Territory University, Darwin.

Clark, M. and S. May (eds) 2013 Macassan History and Heritage: Journeys, Encounters and Influences. Canberra: Australian National University Press.

Clarke, A. and U. Frederick 2011 Making a sea change: Rock art, archaeology and the enduring legacy of Frederick McCarthy's research on Groote Eylandt. In M. Thomas and M. Neale (eds), Exploring the Legacy of the 1948 AmericanAustralian Scientific Expedition to Arnhem Land, pp.135155. Canberra: ANU E Press.

Clarke, P.A. 2003 Where the Ancestors Walked: Australia as an Aboriginal Landscape. Crows Nest, NSW: Allen \& Unwin.

Clarkson, C. 2002 An index of invasiveness for the measurement of unifacial and bifacial retouch: A theoretical, experimental and archaeological verification. Journal of Archaeological Science 29(1):65-75.

Clarkson, C. 2007 Lithics in the Land of the Lightning Brothers: The Archaeology of Wardaman Country, Northern Territory. Terra Australis 25. Canberra: ANU E Press.

Cooper, Z. and S. Bowdler 1998 Flaked glass tools from the Andaman Islands and Australia. Asian Perspectives 37(1):7483.

Dalley, C. and P. Memmott 2010 Domains and the intercultural: Understanding Aboriginal and missionary engagement at the Mornington Island Mission, Gulf of Carpentaria, Australia from 1914 to 1942. International Journal of Historical Archaeology 14(1):112-135.
David, B., I. McNiven, R. Mitchell, M. Orr, S. Haberle, L. Brady and J. Crouch. 2004 Badu 15 and the Papuan-Austronesian settlement of Torres Strait. Archaeology in Oceania 39(2):6578.

David, B. and M. Wilson 1999 Re-reading the landscape: Place and identity in northeast Australia during the late Holocene. Cambridge Archaeological Journal 9(2):163-188.

Davis, R. (ed.) 2004 Woven Histories Dancing Lives: Torres Strait Islander Identity, Culture and History. Canberra: Aboriginal Studies Press.

Embley, J. 1896 Letter to Surveyor General 11th January 1896 [Manuscript ID 103882], Queensland State Archives, Brisbane.

Embley, J. 1897a Survey of Aboriginal Mission River Reserve being Traverse of Embley \& Mission Rivers Cook District, Field Book No 1 [Manuscript C153471], Museum of Lands, Mapping and Surveying, Land and Spatial Information, Department of Natural Resources and Mines, Brisbane.

Embley, J. 1897b Survey of Aboriginal Mission River \& Coast Survey from Port Stewart to Cape Sidmouth, Cook District Field Book No 2 [Manuscript C153471, C153 472], Museum of Lands, Mapping and Surveying, Land and Spatial Information, Department of Natural Resources and Mines, Brisbane.

Embley, J. 1897c Letter to Surveyor General 6th September 1897 [Manuscript 103882], Queensland State Archives, Brisbane.

Embley J. 1897d Weipa Aboriginal Mission Reserve with River Soundings, Cook District [Manuscript C153471], Museum of Lands, Mapping and Surveying, Land and Spatial Information, Department of Natural Resources and Mines, Brisbane.

Embley, J. 1897e The western watershed of the upper portion of Cape York Peninsula. The Royal Geographical Society of Australasia. Queensland 12:26-29.

Frankland, K. 1994 A Guide to Queensland Government Records Relating to Aboriginal and Torres Strait Islander People. Records Guide 1. Brisbane: Queensland State Archives and Department of Family Services and Aboriginal Islander Affairs.

Fullagar, R. 2006 Residues and usewear. In J. Balme and A. Paterson (eds), Archaeology in Practice: A Student Guide to Archaeological Analyses, pp.207-234. Malden: Blackwell Publishing.

Fullagar, R. and L. Head 1997 Hunter-gatherer archaeology and pastoral contact: Perspectives from the northwest Northern Territory, Australia. World Archaeology 28(3):418-428.

Geneste, J.M., B. David, H. Plisson, C. Clarkson, J.J. Delannoy, F. Petchey and R. Whear 2010 Earliest evidence for groundedge axes: $35,400 \pm 410$ cal BP from Jawoyn Country, Arnhem Land. Australian Archaeology 71:66-69.

Gibbs, M. and R. Harrison 2008 Dynamics of dispersion revisited? Archaeological context and the study of Aboriginal knapped glass artefacts in Australia. Australian Archaeology 67:61-68.

Gillet, A. 1986 Opium-Smoking in Australia 1850-1915. Unpublished BA(Hons) thesis, University of Queensland, Brisbane.

Guse [Wesley], D. 2006 'My Country My Home' Land, Law, and Cultural Heritage: A Case Study in the Northern Territory, Australia. Unpublished Masters of Aboriginal and Torres Strait Islander Studies thesis, Charles Darwin University, Darwin. 
Harrison, R. 2000 'Nowadays with glass': Regional variation in Aboriginal bottle glass artefacts from Western Australia. Archaeology in Oceania 35(1):34-47.

Harrison, R. 2002 Archaeology and the colonial encounter: Kimberley spear points, cultural identity and masculinity in the north of Australia. Journal of Social Archaeology 2(3):352-377.

Harrison, R. 2003 The magical virtue of these sharp things: Colonialism, mimesis and knapped bottle glass artefacts in Australia. Journal of Material Culture 8(3):311-336.

Harrison, R. 2005 Contact archaeology and native title. Australian Aboriginal Studies 1:16-29.

Harrison, R. 2006 An artefact of colonial desire? Kimberley points and the technologies of enchantment. Current Anthropology 47(1):63-88.

Harrison, R. 2009 Rationales for the production of Kimberley points: A reply to Akerman. Australian Aboriginal Studies 1:89-91.

Hey, J. 1931 A Brief History of the Presbyterian Church's Mission Enterprise among the Australian Aborigines. Sydney: New Press.

Hiscock, P. 1984 A preliminary report on the stone artefacts from Colless Creek Cave. Queensland Archaeological Research 1:120-151.

Hiscock, P. 2008 Archaeology of Ancient Australia. London: Routledge.

Hiscock, P. and V. Attenbrow 1998 Early backed artefacts from Australia. Archaeology in Oceania 33(2):49-62.

Hitchens, C. 2007 God is Not Great. New York: Allen \& Unwin.

Holdaway, S. and M. Douglass 2011 A twenty-first century archaeology of stone artifacts. Journal of Archaeological Method and Theory 19(1):101-131.

Holtorf, C. 1998 The life-histories of megaliths in MecklenburgVorpomern (Germany). World Archaeology 30(1):23-38.

Hughes, P.J. and R.J. Lampert 1980 Pleistocene occupation of the arid zone in southeast Australia: Research prospects for the Cooper Creek-Strzelecki Desert region. Australian Archaeology 10:52-67.

Hutchinson, D. 1987 Identifying bottles. In J. Birmingham and D. Bairstow (eds), Papers in Australian Historical Archaeology, pp.153-160. Sydney: Australian Society for Historical Archaeology.

Hutton, J. 1922 A History of Moravian Missions. London: Moravian Publication Office.

Huxley, J. (ed.) 1935 T.H. Huxley's Diary of the Voyage of the H.M.S. Rattlesnake. London: Chatto and Windus.

Jack, R.L. 1921a Northmost Australia. Vol. 1. London: Simpkin Marshall, Hamilton Ketn \& Co. Hall Court.

Jack, R.L. 1921b Northmost Australia. Vol. 2. London: Simpkin Marshall, Hamilton Ketn \& Co. Hall Court.

Jackson, C.F.V. 1902 Report on a Visit to the West Coast of the Cape York Peninsula and some Islands of the Gulf of Carpentaria. Brisbane: George Arthur Vaughan, Government Printer, William Street.

Jones, O. and C. Sullivan 1985 The Parks Canada Glass Glossary for the Description of Containers, Tableware, Flat Glass, and Closures. Ottawa: Minister of Supply and Services Canada.
Khan, K. 1993 Catalogue of the Roth Collection of Aboriginal artefacts from north Queensland: Volume 1: Items collected from Archer River, Atherton, Bathurst Head, Bloomfield River and Butcher's Hill, 1897-1901. Technical Reports of the Australian Museum 10:1-205.

Khan, K. 1996 Catalogue of the Roth Collection of Aboriginal artefacts from North Queensland: Volume 2: Items collected from Cairns, Cape Bedford, Cape Grafton, Cape Melville, Cardwell, Clump Point, Coen, Cooktown, Dunk Island, False Cape, Flinders Island, Hambledon, Herberton, Hinchinbrook Island, Ingham, Innisfail, Johnstone River, Kuranda, in 1887 1904. Technical Reports of the Australian Museum 12:1-189.

Khan, K. 2003 Catalogue of the Roth Collection of Aboriginal artefacts from North Queensland: Volume 3: Items collected from McDonnell Electric Telegraph Office, McIvor River, Mapoon and the Pennefather and Wenlock Rivers, Maytown, Mentana, Mitchell River, Morehead River, Moreton Electric Telegraph Office and Musgrave, in 1897-1903. Technical Reports of the Australian Museum 17:1-106.

Khan, K. 2004 Catalogue of the Roth Collection of Aboriginal artefacts from North Queensland: Volume 4: Items collected from Nassau River, Night Island, Palmer River, Peak Point Electric Telegraph Office, Princess Charlotte Bay, Staaten River, Starcke River, Tinaroo, Tully River, Vanrook and Weipa (Embley River), in 1896-1903. Technical Reports of the Australian Museum 18:1-112.

Knudson, R. 1979 Inference and imposition in lithic analysis. In B. Hayden (ed.), Lithic Use Wear Analysis, pp.269-282. New York: Academic Press.

Kociumbas, J. 2004 Genocide and modernity in colonial Australia, 1788-1850. In A. Dirk Moses (ed.), Genocide and Settler Society: Frontier Violence and Stolen Indigenous Children in Australian History, pp.77-102. New York: Berghahn Books.

Larsen, B., S. Holdaway, P. Fanning, T. Mackrell and J. Shiner in press Shape as an outcome of formation history: Terrestrial Laser Scanning of shell mounds from far north Queensland, Australia. Quaternary International.

Leichhardt, L. 1845-1846 Continuation of My Log from the Abel Tasman to Pt Essington the 8 September 1845 [Manuscript C 155, Safe 1/292], Mitchell Library, Sydney.

Leichhardt, L 1847 Journal of an Overland Expedition in Australia from Moreton Bay to Port Essington, A Distance of Upwards of 3000 Miles during the Years 1844-1845. London: T. \& W. Boone.

Loos, N. 1982 Invasion and Resistance: Aboriginal-European Relations on the North Queensland Frontier 1861-1897. Canberra: Australian National University Press.

Macknight, C.C. 1972 Macassans and Aborigines. Oceania 42(4):283-321.

Macknight, C.C. 1986 Macassans and the Aboriginal past. Archaeology in Oceania 21(1):69-75.

Manas, J., B. David, L. Manas, J. Ash and A. Shnukal 2008 An interview with Fr John Manas. Memoirs of the Queensland Museum, Cultural Heritage Series 4(2):261-294.

McCarthy, F.D. 1967 Australian Aboriginal Stone Implements: Including Bone, Shell and Teeth Implements. Sydney: Australian Museum.

McCarthy, F.D. and F.A. Davidson 1943 The Elouera industry of Singleton, Hunter River, New South Wales. Records of the Australian Museum 21(4):210-230. 
McConnel, U. 1939 Social organization of the tribes of Cape York Peninsula, North Queensland. Oceania 10(1):54-72.

McConnel, U. 1940 Social organization of the tribes of Cape York Peninsula, North Queensland (continued). Oceania 10(4):434-455.

McNiven, I.J., B. David and J. Flood 1992 Delamere 3: Further excavations at Yiwarlarlay (Lightning Brothers site), Northern Territory. Australian Aboriginal Studies 1:67-73.

Meston, A. 1895 Queensland Aboriginals: Proposed System for their Improvement and Preservation. Brisbane: Government Printer.

Meston, A. 1896 Report on the Aboriginals of Queensland. Brisbane: Government Printer.

Meston, A. 1897a Wild Country and Wild Tribes I. The Queenslander 9 January.

Meston, A. 1897b Wild Country and Wild Tribes II. The Queenslander 16 January.

Meston, A. 1897c Wild Country and Wild Tribes III. The Queenslander 23 January.

Meston, A. 1897d Wild Country and Wild Tribes IV. The Queenslander 30 January.

Meston, A. 1897e Wild Country and Wild Tribes V. The Queenslander 6 February.

Meston, A. 1897f Wild Country and Wild Tribes VI. The Queenslander 13 February.

Meston, A. 1897g Wild Country and Wild Tribes VII. The Queenslander 20 February.

Meston, A. 1897h Wild Country and Wild Tribes VIII. The Queenslander 27 February.

Meston, A. 1897i Wild Country and Wild Tribes IX. The Queenslander 6 March.

Meston, A. 1897j Wild Country and Wild Tribes X. The Queenslander 13 March.

Meston, A. 1897k Wild Country and Wild Tribes XI. The Queenslander 20 March.

Meston, A. 18971 Wild Country and Wild Tribes XII. The Queenslander 27 March.

Meston, A. $1897 \mathrm{~m}$ Wild Country and Wild Tribes XIII. The Queenslander 3 April.

Meston, A. 1897n Wild Country and Wild Tribes XIV. The Queenslander 10 April.

Meston, A. 1897o Wild Country and Wild Tribes XV. The Queenslander 17 April.

Mitchell, S. 1996 Dugongs and dugouts, sharptacks and shellbacks: Macassan contact and Aboriginal marine hunting on the Coburg Peninsula, north-western Arnhem Land. Bulletin of the Indo-Pacific Prehistory Association ChiangMai Papers 2(15):181-191.

Mitchell, S. 2000 Guns or barter? Indigenous exchange networks and the mediation of conflict in post-contact western Arnhem Land. In R. Torrence and A. Clarke (eds), The Archaeology of Difference: Negotiating Cross-Cultural Engagements, pp.182-214. Hoboken: Routledge.

Monchamp, A M. 2014 Autobiographical Memory in an Aboriginal Australian Community: Culture, Place and Narrative. New York: Palgrave Macmillan.
Moore, D. 1965 The Tribes at Cape York: A Reconstruction of their Way of Life from the Literature and a Consideration of its Relevance to the Archaeology of the Area. Unpublished Thesis for Diploma in Anthropology, Department of Anthropology, University of Sydney, Sydney.

Moore, D. 1979 Islanders and Aborigines at Cape York: An Ethnographic Reconstruction based on the 1848-1850 'Rattlesnake' Journals of $O$. W. Brierly and Information he Obtained from Barbara Thompson. New Jersey: Humanities Press.

Morrison, M. 2010 The Shell Mounds of Albatross Bay: An Archaeological Investigation of Late Holocene GathererHunter Production Strategies near Weipa, North Eastern Australia. Unpublished $\mathrm{PhD}$ thesis, Flinders University, Adelaide.

Morrison, M. 2013 Niche production strategies and shell matrix site variability at Albatross Bay, Cape York Peninsula. Archaeology in Oceania 48(2):78-91.

Morrison, M. 2014 Chronological trends in late Holocene shell mound construction across northern Australia: Insights from Albatross Bay, Cape York Peninsula. Australian Archaeology 79:1-13.

Morrison, M. 2015 Late Holocene Aboriginal shellfish production strategies in northern Australia: Insights from Prunung (Red Beach), Weipa, Cape York Peninsula. Queensland Archaeological Research 18:1-27.

Morrison, M. and E. Shepard 2013 The archaeology of culturally modified trees: Indigenous economic diversification within colonial intercultural settings in Cape York Peninsula, northeastern Australia. Journal of Field Archaeology 38(2):143-160

Morrison, M., D. McNaughton and C. Keating 2015 "Their God is their belly": Moravian missionaries at the Weipa Mission (1898-1932), Cape York Peninsula. Archaeology in Oceania 50(2):85-104.

Morrison, M., D. McNaughton and J. Shiner 2010 Mission-based Indigenous production at the Weipa Presbyterian Mission, Western Cape York Peninsula (1932-66). International Journal of Historical Archaeology 14(1):86-111.

Morwood, M.J. and D.R. Hobbs 2002 Visions from the Past: The Archaeology of Australian Aboriginal Art. St Leonards, NSW: Allen and Unwin.

Moseley, H. 1879 Notes by a Naturalist on the Challenger being an Account of Various Observations Made during the Voyage of H.M.S Challenger round the World in the Years 18721876. London: Macmillan and Co.

Mulvaney, K. 2010 Murujuga Marni-Dampier Petroglyphs: Shadows in the Landscape, Echoes across Time. Unpublished $\mathrm{PhD}$ thesis, University of New England, Armidale.

Napranum Cha [Weipa, Cape York] 1986 "Making out Dugout Canoe" 1-10 September. Weipa, Cape York.

Napranum Cha [Weipa, Cape York] 1987 “Camp Amban” 15-19 June. Weipa, Cape York.

Niemoeller, G. 1999 Culture Contact on Bradshaw Station in the Victoria River Region, Northern Territory. Unpublished BA(Hons) thesis, Department of Anthropology and Sociology, University of Queensland, Brisbane.

Niemoeller, G. and D. Guse 1999 Inter-regional variation in glass bottle reduction and technology in the Northern Territory. Australian Archaeology 48:47-48. 
O'Connor, S., K. Aplin and S. Collins 2008 A small salvage excavation in Windjana Gorge, Kimberley, Western Australia. Archaeology in Oceania 43(2):75-81.

Ó Foghlú B in press Sustaining cultural identity through environmental sustainability: Earth mounds in Northern Australia, c2200BP to present. In Shallow Pasts, Endless Horizons: Sustainability and Archaeology: Proceedings of the 48th Annual Chacmool Archaeological Conference. University of Calgary November 11-14, 2015.

Olick, J. 1999 Collective memory: The two cultures. Sociological Theory 17(3)333-348.

Olick, J. 2007 From usable pasts to the return of the repressed. Hedgehog Review Summer: 19-31.

Olick, J. 2008 Collective memory. In W. Darity (ed.), International Encyclopaedia of the Social Sciences: Volume 1: Abortion-Cognitive Dissonances, pp.7-8. 2nd ed. Michigan: Macmillan Reference.

Olick, J. and J. Robbins 1998 Social memory studies: From "Collective Memory" to the historical sociology of mnemonic practices. Annual Review of Sociology 24:105140 .

Parry-Okeden, W.E. 1897 Report on the North Queensland Aborigines and the Native Police. Queensland Legislative Assembly Votes and Proceedings 2.

Reid, A. 2013 Crossing the great divide: Australian and eastern Indonesia. In M. Clark and S. May (eds), Macassan History and Heritage: Journeys, Encounters and Influences, pp.4154. Canberra: Australian National University Press.

Robert, W. 1973 The Dutch Explorations of Australia 1605-1756. Amsterdam: Philo Press.

Roberts, R.G., R. Jones, N.A. Spooner, M.J. Head, A.S. Murray and M.A. Smith 1994 The human colonisation of Australia: Optical dates of 53,000 and 60,000 years bracket human arrival at Deaf Adder Gorge, Northern Territory. Quaternary Science Reviews 13(5):575-583.

Robins, R.P., E.C. Stock and D.S. Trigger 1998 Saltwater people, saltwater country: Geomorphological, anthropological and archaeological investigations of the coastal lands in the southern Gulf Country of Queensland. Memoirs of the Queensland Museum Cultural Heritage Series 1(1):75-125.

Rosendahl, D. 2012 The Way it Changes Like the Shoreline and the Sea: The Archaeology of the Sandalwood River, Mornington Island, Southeast Gulf of Carpentaria, Australia. Unpublished $\mathrm{PhD}$ thesis, The University of Queensland, Brisbane.

Roth, W.E. 189(?) Letter to Baldwin Spencer 10th May 189(?) [Manuscript D2], Walter Baldwin Spencer Papers Collection, Pitt Rivers Museum, University of Oxford.

Roth, W.E. 1897 Letter to Baldwin Spencer 22nd December 1897 [Manuscript D3], Walter Baldwin Spencer Papers Collection, Pitt Rivers Museum, University of Oxford.

Roth, W.E. 1898a Letter to Baldwin Spencer 19th January 1898 [Manuscript D4], Walter Baldwin Spencer Papers Collection, Pitt Rivers Museum, University of Oxford.

Roth, W.E. 1898b Letter to Baldwin Spencer 8th October 1898 [Manuscript D5], Walter Baldwin Spencer Papers Collection, Pitt Rivers Museum, University of Oxford.

Roth, W.E. 1899a Letter to Baldwin Spencer 2nd March 1899 [Manuscript D6], Walter Baldwin Spencer Papers Collection, Pitt Rivers Museum, University of Oxford.
Roth, W.E. 1899b Letter to Baldwin Spencer 28th March 1899 [Manuscript D7], Walter Baldwin Spencer Papers Collection, Pitt Rivers Museum, University of Oxford.

Roth, W.E. 1899c Letter to Baldwin Spencer 12th November 1899 [Manuscript D8], Walter Baldwin Spencer Papers Collection, Pitt Rivers Museum, University of Oxford.

Roth, W.E. 1900a Letter to Baldwin Spencer 10th January 1900 [Manuscript D9], Walter Baldwin Spencer Papers Collection, Pitt Rivers Museum, University of Oxford.

Roth, W.E. 1900b Report [to the Commissioner of Police, Queensland] on the Aboriginals of the Pennefather (Coen) River District and other Coastal Tribes Occupying the Country between the Batavia and Embley Rivers [visited by the Minister during his last trip]; with Vocabularies and Anthropometric Charts. Cooktown, 8 January 1900 [Manuscript Microfilm CY 208], Mitchell Library, Sydney, New South Wales.

Roth, W.E. 1900c Report of the Northern Protector of Aboriginals for 1899. Brisbane: Government Printer.

Roth, W.E. 1901 a Ethnology: Aboriginal food. The Queenslander 23 November.

Roth, W.E. 1901b North Queensland Ethnography. Bulletin No. 1: String and other forms of Strand: Basketry, Woven Bagand Net-Work. Brisbane: Queensland Government Printer.

Roth, W.E. 1901c North Queensland Ethnography. Bulletin No. 2: The Structure of the Koko-Yimidir Language. With the Assistance of Revs. G.H. Schwarz and W. Poland, Lutheran Missionaries at Cape Bedford Mission Station. Brisbane: Government Printer.

Roth, W.E. 1901d North Queensland Ethnography. Bulletin No. 3: Food: Its Search, Capture and Preparation. Brisbane: Government Printer.

Roth, W. E. 1901e Annual Report of the Northern Protector of Aboriginals for 1900. Brisbane: Government Printer.

Roth, W.E. 1902a Letter to Baldwin Spencer 2nd April 1902 [Manuscript D10], Walter Baldwin Spencer Papers Collection, Pitt Rivers Museum, University of Oxford.

Roth, W.E. 1902b Letter to Baldwin Spencer 26th April 1902 [Manuscript D11], Walter Baldwin Spencer Papers Collection, Pitt Rivers Museum, University of Oxford.

Roth, W.E. 1902c Letter to Baldwin Spencer 26th April 1902 [Manuscript D11], Walter Baldwin Spencer Papers Collection, Pitt Rivers Museum, University of Oxford.

Roth, W. E. 1902d Letter to Baldwin Spencer 6th October 1902 [Manuscript D12], Walter Baldwin Spencer Papers Collection, Pitt Rivers Museum, University of Oxford.

Roth, W.E. 1902e North Queensland Ethnography. Bulletin No. 4: Games, Sports and Amusements. Brisbane: Government Printer.

Roth, W.E. 1902f Annual Report of the Northern Protector of Aboriginals for 1901. Brisbane: Government Printer.

Roth, W.E. 1903a Letter to Baldwin Spencer 8th February 1903 [Manuscript D14], Walter Baldwin Spencer Papers Collection, Pitt Rivers Museum, University of Oxford.

Roth, W. E. 1903b Letter to Baldwin Spencer dated January 1903 [Manuscript D15], Walter Baldwin Spencer Papers Collection, Pitt Rivers Museum, University of Oxford.

Roth, W.E. 1903c North Queensland Ethnography. Bulletin No. 5: Superstition, Magic and Medicine. Brisbane: Government Printer. 
Roth, W.E. 1903d North Queensland Ethnography. Bulletin No. 6: An Elementary Grammar of the Nggerikudi Language. By the Rev. N. Hey, Superintendent of the Presbyterian Mission, Mapoon, Batavia River, North Queensland. Brisbane: Government Printer.

Roth, W.E. 1903e Annual Report for the Northern Protector of Aboriginals for 1902. Brisbane: Government Printer.

Roth, W.E. 1904a North Queensland Ethnography. Bulletin No. 7: Domestic Implements, Arts, and Manufactures. Brisbane: Government Printer.

Roth, W.E. 1904b Annual Report of the Chief Protector of Aboriginals for 1903. Brisbane: Government Printer.

Roth, W.E. 1905a North Queensland Ethnography. Bulletin No. 8: Notes on Government, Morals, and Crime. Brisbane: Government Printer.

Roth, W.E. 1905b Annual Report of the Chief Protector of Aboriginals for 1904. Brisbane: Government Printer.

Roth, W.E.1906 Annual Report of the Chief Protector of Aboriginals for 1905. Brisbane: Government Printer.

Roth, W.E. 1907 North Queensland Ethnography. Bulletin No. 9: Burial Ceremonies, and Disposal of the Dead. Records of the Australian Museum 6(5):365-403, pls. 68-74.

Roth, W.E. 1908a North Queensland Ethnography. Bulletin No. 10: Marriage Ceremonies and Infant Life. Records of the Australian Museum 7(1):1-17, pls. 1-3.

Roth, W.E. 1908b North Queensland Ethnography. Bulletin No. 11: Miscellaneous Papers. 1. Tabu and other forms of restriction. 2. Counting and enumeration. 3. Signals on the road; gesture language. 4. Progressive Koko-Yimidir exercises. Records of the Australian Museum 7(2):74-107, pls. 17-21.

Roth, W.E. 1909a North Queensland Ethnography. Bulletin No. 12: On Certain Initiation Ceremonies. Records of the Australian Museum 7(3):166-185, pls. 50-56.

Roth, W.E. 1909b North Queensland Ethnography. Bulletin No. 13: Fighting Weapons. Records of the Australian Museum 7(4):189-211, pls. 58-61.

Roth, W.E. 1910a North Queensland Ethnography. Bulletin No. 14: Transport and Trade. Records of the Australian Museum 8(1):1-19, figs. 1-13, pls. 1-7.

Roth, W.E. 1910b North Queensland Ethnography. Bulletin No. 15: Decoration, Deformation and Clothing. Records of the Australian Museum 8(1):20-54, figs. 14-30, pls. 8-10.

Roth, W.E. 1910c North Queensland Ethnography. Bulletin No. 16: Huts and Shelters. Records of the Australian Museum 8(1):55-66, figs. 31-42, pls. 11-17.

Roth, W.E. 1910d North Queensland Ethnography. Bulletin No. 17: Postures and Abnormalities. Records of the Australian Museum 8(1):67-78, figs. 43-51, pls. 18-24.

Roth, W.E. 1910e North Queensland Ethnography. Bulletin No. 18: Social and Individual Nomenclature. Records of the Australian Museum 8(1):79-106, pls. 25-31.

Russell, L. 2001 Colonial Frontiers: Indigenous-European Encounters in Settler Societies. New York: Manchester University Press.

Ryan, I. and K. Morse 2009 Towards a late Holocene archaeology of the inland Pilbara. Archaeology in Oceania 44(1):6-15.

Scambary, B. 2013 My Country, Mine Country: Indigenous People, Mining and Development Contestation in Remote Australia. Canberra: Australian National University Press.
Schilder, G. 1975 Australia Unveiled: The Share of the Dutch Navigators in the Discovery of Australia. Amsterdam: Theatrvm Orbis Terrarvm.

Sharp, N. 1992 Footprints along the Cape York Sandbeaches. Canberra: Aboriginal Studies Press.

Sheehan, C. 2008 Strangers and servants of the company: The United East India Company and the Dutch voyages to Australia. In P. Veth, P. Sutton and M. Neale (eds), Strangers on the Shore: Early coastal contacts in Australia, pp.6-30. Canberra: National Museum of Australia Press.

Shiner, J., P. Fanning, S. Holdaway, F. Petchey, C. Beresford, E. Hoffman and B. Larsen 2013 Shell mounds as the basis for understanding human-environment interactions in far north Queensland, Australia. Queensland Archaeological Research 16:45-64.

Shiner, J. and M. Morrison 2009 The contribution of heritage surveys towards understanding the cultural landscape of the Weipa bauxite plateau. Australian Archaeology 68:52-55.

Sim, R. and L.A. Wallis 2008 Northern Australian offshore island use during the Holocene: The archaeology of Vanderlin Island, Sir Edward Pellew Group, Gulf of Carpentaria. Australian Archaeology 67:95-106.

Smith, G. 1891 Cruise of the S.S. Vigilant: The Blacks of the Gulf Country. The Brisbane Courier 31 March.

Smith, M.A. 2006 Characterizing late Pleistocene and Holocene stone artefact assemblages from Puritjarra rock shelter: A long sequence from the Australian desert. Records of the Australian Museum 58(3):371-410.

Spencer, W.B. 1903 Letter to Walter Roth 30th January 1903 [Manuscript D13], Walter Baldwin Spencer Papers Collection, Pitt Rivers Museum, University of Oxford.

Stevenson, J., S. Brockwell, C. Rowe, U. Proske and J. Shiner 2015 The palaeoenvironmental history of Big Willum Swamp, Weipa: An environmental context for the archaeological record. Australian Archaeology 80:17-31.

Stone, T. 1992 Origins of the Weipa Shell Mounds. Unpublished MSc thesis, Department of Geography, The Australian National University, Canberra.

Sullivan, M., P. Hughes and A. Barham 2011 Changing perspectives in Australian archaeology. Part II. Abydos Plain - Equivocal archaeology. Technical Reports of the Australian Museum 23(2):7-29.

Sutton, P. 2008 Stories about feeling: Dutch-Australian contact in Cape York Peninsula, 1606-1756. In P. Veth, P. Sutton and M. Neale (eds), Strangers on the Shore: Early Coastal Contacts in Australia, pp.31-54. Canberra: National Museum of Australia Press.

Sutton, P. 2010 The logic of Wik camping. In K. Hardy (ed.), Archaeological Invisibility and Forgotten Knowledge, pp.91107. British Archaeological Reports International Series S2183. Oxford: Archaeopress.

Tamm, M. (ed.) 2015 Afterlife of Events: Perspectives on Mnemohistory. New York: Palgrave Macmillan.

Taylor, C. 2003 Constructing Aboriginality: Archibald Meston's literary journalism, 1870-1924. Journal of the Association for the Study of Australian Literature 2:121-139.

Ulm, S., T. Eales and S. L'Estrange 1999 Post-European Aboriginal occupation of the southern Curtis Coast, Central Queensland. Australian Archaeology 48:42-43. 
Ulm, S., N. Evans, D. Rosendahl, P. Memmott and F. Petchey 2010 Radiocarbon and linguistic dates for occupation of the South Wellesley Islands, northern Australia. Archaeology in Oceania 45(1):39-43.

Ulm, S., K. Vernon, G. Robertson and S. Nugent 2009 Historical continuities in Aboriginal land-use at Bustard Bay, Queensland: Results of use-wear and residue analysis of Aboriginal glass artefacts. Australasian Historical Archaeology 27:111-119.

Urquhart, F C. 1897 Albatross Bay and the Embley and Hey Rivers. Proceedings of the Royal Society of Queensland 12:42-46.

Wallace, L. 2012 Cape York Peninsula: A History of Unlauded Heroes 1845-2003. Brisbane: Boolarong Press.

Ward, A. 1908 The Miracle of Mapoon or from Native Camp to Christian Village. London: S. W. Partridge \& Co., Moravian Mission Agency.

Ward, I. 2004 Comparative records of occupation in the Keep River region of the eastern Kimberley, northwestern Australia. Australian Archaeology 59:1-9.
Ward, I., R. Fullagar, T. Boer-Mah, L.M. Head, P.S.C. Taçon and K. Mulvaney 2006 Comparison of sedimentation and occupation histories inside and outside rock shelters, KeepRiver region, northwestern Australia. Geoarchaeology 21(1):1-27.

Watchman, A. 1985 Mineralogical Analysis of Silica Skins Covering Rock Art in R. Jones (ed.), Archaeological Research in Kakadu National Park, pp.281-289. Canberra: Australian National Parks and Wildlife Service.

Wolski, N. and T.H. Loy 1999 On the invisibility of contact: Residue analyses on Aboriginal glass artefacts from western Victoria. The Artefact 22:65-73.

Wright, D. 2011 Mid Holocene maritime economy in the western Torres Strait. Archaeology in Oceania 46(1):23-27.

Wright, D. and G. Jacobsen 2013 Further radiocarbon dates from Dabangay, a mid- to late Holocene settlement site in western Torres Strait. Australian Archaeology 76:79-83. 